\title{
Multi-platform observations of a springtime case of Bodélé and Sudan dust emission, transport and scavenging over West Africa
}

\author{
C. Flamant ${ }^{\mathrm{a} *}$ C. Lavaysse ${ }^{\mathrm{a}}$, M. C. Todd ${ }^{\mathrm{b}}$, J.-P. Chaboureau ${ }^{\mathrm{c}}$ and J. Pelon ${ }^{\mathrm{a}}$ \\ ${ }^{a}$ Service d'Aéronomie/Institut Pierre-Simon Laplace, Université Pierre et Marie Curie and CNRS, Paris, France \\ ${ }^{\mathrm{b}}$ Department of Geography, University College London, UK \\ ${ }^{\mathrm{c}}$ Laboratoire d'Aérologie, Université de Toulouse and CNRS, Toulouse, France
}

\begin{abstract}
The structure of the Saharan air layer over Niger and Benin during a major springtime dust event from the Bodélé region and Sudan is investigated using airborne lidar and dropsonde measurements. Aircraft operations were conducted on 13 and 14 June 2006, within the framework of the African Monsoon Multidisciplinary Analysis Special Observing Period. Complementary ground-based and satellite observations, as well as European Centre for Medium-range Weather Forecasts analyses are used to investigate the regional aspects of emission, transport and deposition in the period from 9 to 14 June 2006, to provide a framework for the interpretation of the airborne measurements. The study details the transport patterns of dust from eastern Saharan sources towards the southwest in the springtime, and highlights the role of the intertropical discontinuity and the Darfur mountains in injecting the aerosols from Bodélé and Sudan, respectively, over the monsoon flow, and in the African easterly jet (AEJ) region. It also illustrates the impact of the daily variability of the emissions in the source regions on the dust load advected westward by the AEJ and observed over Benin. The impact of a mesoscale convective system (MCS) on the dust load and vertical distribution observed over Benin and southern Niger was also investigated, nearly 12 hours after its passage over Benin. The only discernible impact on the dust distribution is observed to be associated with widespread subsidence in the wake of the MCS, over northern Benin and Niger. Wet scavenging related to convective or stratiform rain could not be observed, as processed air masses were replaced by fresh dust transported in the upper Saharan air layer by the AEJ. Over southern Benin, the dust distribution appeared to be mostly controlled by processes affecting the planetary boundary layer upstream, i.e. over Nigeria or Chad. Because springtime dust from remote eastern sources (such as observed in this case) is mainly transported into the AEJ, it could impact on the radiation budget in the AEJ region, thereby possibly modifying the West African weather at the synoptic scale.
\end{abstract}

KEY wORDS AMMA; Saharan air layer; African easterly jet; lidar; dropsondes; SEVIRI; CALIOP; MODIS; OMI

\section{Introduction}

The impact of dust on the climate system and the large uncertainties associated with the role of dust in the Earth's radiation budget is now widely recognized (e.g. IPCC, 2008). North Africa is the world's largest source of mineral dust. Satellite sensors consistently indicate that dust aerosol plumes are the most widespread, persistent and dense found on Earth (e.g. Prospero et al., 2002).

While attempting to establish the impact of dust on the Earth's radiation budget over Africa, one particularly important aspect is knowledge of the three-dimensional distribution at the regional scale, and the associated temporal evolution. North African dust emissions and transport have been shown to be highly variable in time and space (e.g. Prospero et al., 2002; Engelstaedter and

\footnotetext{
${ }^{*}$ Correspondence to: C. Flamant, Service d'Aéronomie, Institut PierreSimon Laplace, Tour 45, Boite 102, Université Pierre et Marie Curie, 4 Place Jussieu, 75252 Paris Cedex 05, France.

E-mail: cyrille.flamant@aero.jussieu.fr
}

Washington, 2007). Failure to represent variability in aerosol concentrations over the Sahara can account for significant errors in model representation of the Saharan heat low thermodynamics and pressures (Haywood et al., 2005). Furthermore, Tompkins et al. (2005) have highlighted how improvements in aerosol representation in the European Centre for Medium-Range Weather Forecasts (ECMWF) model significantly improves the 5-day forecasts for the West African monsoon. They have shown that a more realistic representation of the threedimensional fields of dust led to improved representation of the structure and position of the African easterly jet (AEJ), a central feature of the West African weather playing an important role in the organisation and propagation of mesoscale convective systems (MCSs) and in the transport of dust across the African continent.

The late spring and the early summer is arguably the period when the dust load over West Africa (and particularly the Sahel) is largest (e.g. Engelstaedter and Washington, 2007). It is also a period when the dust load over Sahelian and sub-Sahelian countries exhibits 
the largest temporal and spatial variability, both in the horizontal and the vertical. This is related to:

(i) the presence of the intertropical discontinuity (ITD) over the Sahel which has been shown to favour the uplift of dust during the night-time when the leading edge of the monsoon flow exhibits the characteristics of a density current (Bou Karam et al., 2008),

(ii) the occurrence of the first MCSs over Sahel (south of the ITD) and their associated cold pools which offer an efficient mechanism for dust lifting and injection to altitudes favourable for long-range transport, before the growing vegetation rapidly inhibits local dust emission (e.g. Sterk, 2002; Flamant et al., 2007; Marsham et al., 2008), and

(iii) the strong harmattan winds to the north of the ITD which can generate large uplift of dust from the North African sources in the form of discrete outbreaks (Knippertz, 2008).

In the case of mechanisms (i) and (ii), the mobilized dust is lifted and advected away and to the rear of the leading edge of the monsoon due to the closed circulation characteristic of the density current. This elevated dust is then mixed throughout the depth of the Saharan and/or Sahelian planetary boundary layer (PBL) during the day as the result of the turbulent mixing and becomes available for long-range transport. As a result, dust layers over sub-Sahelian countries are mostly observed to be contained within the Saharan air layer (SAL), an elevated layer (roughly at the altitude of the AEJ), after being previously transported southwestward with the harmattan from the Sahel and the Sahara.

Even though transport of massive amounts of dust in the SAL could impact on the atmospheric stratification in the AEJ region and the properties of the AEJ itself, thereby possibly modifying the West African weather at the synoptic scale, the processes driving the vertical distribution of dust (and its variability) within the SAL over the sub-Sahel during spring/summer have received little attention so far.

In this paper, we analyse the processes (emission, transport and deposition) affecting the dust load and vertical distribution in the SAL at the regional scale during a major springtime dust event from the Bodélé region and Sudan, within the framework of the African Monsoon Multidisciplinary Analysis (AMMA; Redelsperger et al., 2006) Special Observing Period (SOP 1a).

The SAL structure and the vertical distribution of dust are investigated using airborne observations acquired on 13 and 14 June 2006 over Benin, before and after, respectively, the passage of an MCS which initially developed in the afternoon of 13 June in the vicinity of the Jos plateau (Nigeria) and travelled across Benin in the morning of 14 June. (Figure 1 gives details of relevant geographical features.) Complementary groundbased and satellite observations, as well as ECMWF analyses, are used to investigate the regional aspects of emission, transport and deposition mechanisms in the period from 9 to 14 June 2006 to provide a framework for the interpretation of the airborne measurements made on 13 and 14 June 2006. Particular attention is given to the fluctuations of dust load at the interdiurnal time-scales between Benin and the source regions, in order to correctly interpret the observations.

To the best of the authors' knowledge, this paper is one of the few studies to describe the transport patterns of dust from eastern North African sources towards the southwest in the late spring, and to highlight the role of the intertropical discontinuity (ITD) and the Darfur mountains in injecting the aerosols from Bodélé and Sudan, respectively, over the monsoon flow and into the AEJ region. Parker et al. (2005) and Knippertz et al. (2008) discuss the transport from the Saharan PBL over the monsoon in the SAL, although they do not mention the role of orography in this process. The transport of dust in harmattan air over the ITD and the monsoon layer is discussed by Hamilton and Archbold (1945) to some extent.

Furthermore, the lidar measurements presented in this paper are the first to be obtained across the AEJ region before and after the passage of an MCS, and to provide a picture of the SAL structure at the regional scale.

The remainder of the paper is organized as follows. After describing, in section 2, the data utilized in this study, we focus on the synoptic situation (section 3). In section 4, we detail the emission, transport and scavenging processes leading to the regional distribution of aerosols from 9 to 14 June 2006, while in section 5, the life cycle of the 13-14 June MCS is presented. Section 6 focuses on the airborne and space-borne observations of the vertical distribution of dust over southern Niger and Benin, as well as upstream, on 13 and 14 June. The paper concludes with a summary and a discussion in section 7 .

\section{Data sources}

2.1. AMMA-related ground-based and airborne observations

\subsubsection{Airborne data}

The airborne lidar and dropsonde measurements described herein were made during a 'north-south landatmosphere-ocean interaction' mission over Benin, the southwestern extremity of Niger and of the Gulf of Guinea by the Service des Avions Français Instrumentés pour la Recherche en Environnement (SAFIRE) Falcon 20 (F/F20) on 13 and 14 June 2006 (Figure 1). The vertical distribution of the aerosols together with the atmospheric dynamics and thermodynamics were documented at the regional scale using the airborne lidar LEANDRE 2 (Bruneau et al., 2001; Flamant et al., 2007) and dropsonde measurements along the meridian transects performed at $1.5^{\circ} \mathrm{E}$ on 13 June and between $2.15^{\circ}$ and $2.5^{\circ} \mathrm{E}$ on 14 June, spanning from $15^{\circ} \mathrm{N}$ to $4^{\circ} \mathrm{N}$ (Figure 1 ). The F/F20 was flying at $8000 \mathrm{~m}$ above mean sea level (amsl). Operations were conducted between 1130 and 1330 UTC, and 1300 and 1500 UTC, on 13 and 14 June, respectively. Twelve dropsondes were released on 13 June and one on 14 June. Dropsonde data were processed with the Atmospheric Sounding Processing Environment software (version 2.6.5 of July 2006). 


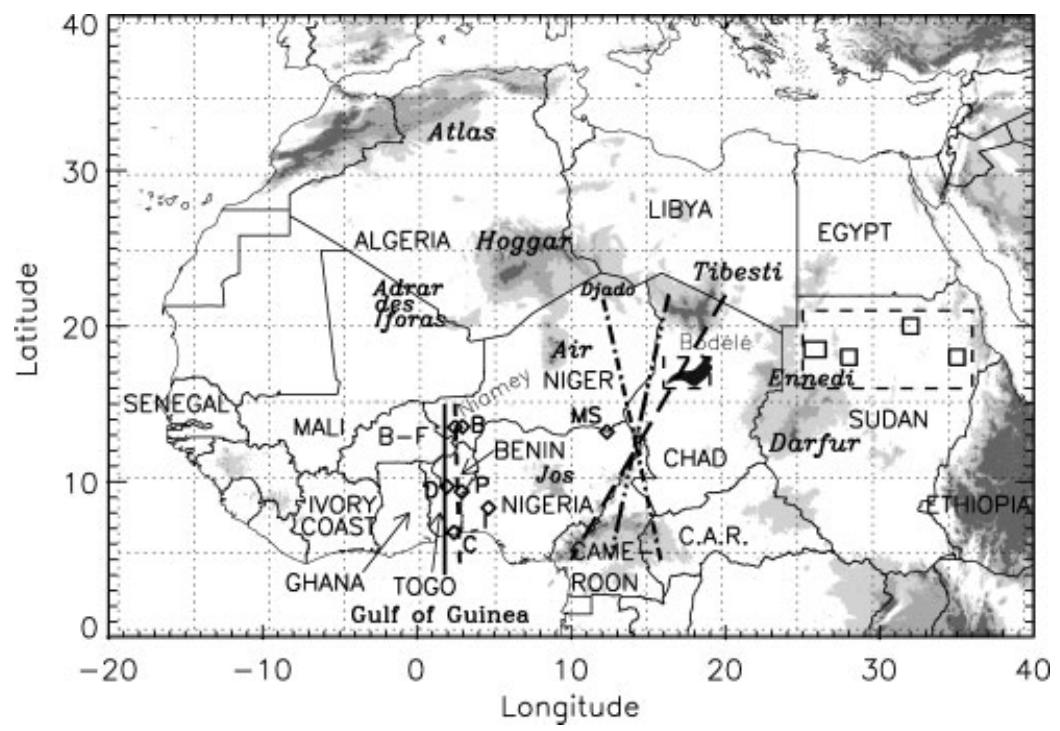

Figure 1. Map of North and West Africa with geographical labels (main orographic features appearing in italic). The grey shading indicates terrain height above mean sea level (m): 650, 1000 and $1500 \mathrm{~m}$ from light to dark grey. The black shading indicates the location of the Bodélé depression (terrain below $250 \mathrm{~m}$ amsl). The thick solid (short-dashed) line near $2^{\circ}$ E represents the F/F20 flight track on 13 (14) June 2006 . The long-dashed line indicates the loction of the cross-sections shown in Figure 7. The dash-dotted line (dash-dot-dot-dotted line) represents the CALIPSO track on 13 June at 1239 UTC (14 June at 0041 UTC). B, C, D, P, I and MS denote Banizoumbou, Cotonou, Djougou, Parakou, Ilorin and Maine-Soroa, respectively. B-F and C.A.R. denote Burkina-Faso and Central African Republic, respectively. The two dashed boxes represent the Bodélé and broad Sudanese souce regions. The smaller solid boxes within the Sudanese box correspond to the sources described in Prospero et al. (2002).

LEANDRE-derived reflectivity at $730 \mathrm{~nm}$ is mostly sensitive to aerosols with radii ranging from 0.1 to $5 \mu \mathrm{m}$, and hence to dust aerosols. Furthermore, reflectivity is sensitive to aerosol optical properties and concentration, as well as relative humidity in the case of hygroscopic aerosols. However, over the African continent, close to the sources, desert dust particles are generally considered to be hygrophobic (e.g. Fan et al., 2004). Therefore, reflectivity associated with desert dust is generally not expected to be sensitive to relative humidity fluctuations, and can be used as a proxy for dust concentration.

In order to facilitate the comparison between the lidar measurements acquired on 13 and 14 June, the lidar reflectivity profiles were normalized to the value of the molecular backscatter coefficient (at $730 \mathrm{~nm}$ ) at an altitude of $6 \mathrm{~km}$ amsl (i.e. above the dust plume). The resulting lidar-derived attenuated backscatter coefficient (ABC) fields are used in this paper to analyse the twodimensional distribution of dust at high resolution $(15 \mathrm{~m}$ in the vertical and $1.5 \mathrm{~km}$ in the horizontal). Molecular backscatter coefficient profiles (at $730 \mathrm{~nm}$ ) were obtained from dropsonde pressure and temperature measurements.

Lidar-derived ABCs are also used to compute the integrated particle backscatter coefficient (a proxy for the dust content) along the transect. First, particle backscatter coefficients were computed by subtracting a mean molecular backscatter coefficient profile (obtained by averaging all available dropsonde profiles) from the lidar-derived ABCs. The integrated particle backscatter coefficients corresponding to the elevated dust plume were then obtained by integrating the particular backscatter coefficients for a given profile between the base and the top of the dust plume.

\subsubsection{Regional networks}

As a complement to the Moderate-resolution Imaging Spectroradiometer (MODIS) observations, we also utilise observations of aerosol optical depth (AOD, at 440 and $675 \mathrm{~nm}$ ) derived from sun-photometer retrievals acquired within the framework of the Aerosol Robotic Network (AERONET). The level 2.0 (cloud-screened) data from stations distributed over the Sahelian region, namely Banizoumbou (Niger; $13.54^{\circ} \mathrm{N}, 2.66^{\circ} \mathrm{E}$ ), Maine-Soroa (Niger; $13.28^{\circ} \mathrm{N}, 12.02^{\circ} \mathrm{E}$ ), and the sub-Sahel, namely Djougou (Benin; $9.76^{\circ} \mathrm{N}, 1.6^{\circ} \mathrm{E}$ ) and Ilorin (Nigeria; $8.32^{\circ} \mathrm{N}, 4.34^{\circ} \mathrm{E}$ ) are used (Figure 1 shows locations).

\subsection{Space-borne observations}

\subsubsection{Regional distribution of dust}

The regional distribution of dust aerosols was described using three complementary satellite products. First, the Ozone Monitoring Instrument (OMI) daily Aerosol Index (AI) product, which has a daily observation time of 1300 UTC, was used. Second, MODIS fields of AOD were obtained from the MODIS/AQUA collection 005 over vegetated surfaces, and the MODIS/AQUA Deep Blue Collection 005 over desert surfaces (MOD08 product). No data from the MODIS Deep Blue Collection were available on 14 June. Third, the vertical distribution of the aerosols was documented at the regional scale using the spaceborne Cloud-Aerosol LIdar with Orthogonal Polarization (CALIOP; Winker et al., 2007) on board the Cloud-Aerosol Lidar and Infrared Pathfinder Satellite Observations (CALIPSO) satellite (launched in April 2006). The CALIOP-derived reflectivity at $532 \mathrm{~nm}$ was analysed along two overpasses (between 1236 and 
1241 UTC on 13 June and between 0050 and 0055 UTC on 14 June), just west of the Bodélé region (Figure 1). $\mathrm{ABCs}$ at $532 \mathrm{~nm}$ were obtained after normalisation of the reflectivity profiles to the molecular backscatter coefficient profiles (at $532 \mathrm{~nm}$ ) derived from molecular density profiles extracted from the National Centers for Environmental Prediction (NCEP) along CALIPSO tracks.

\subsubsection{Regional distribution of cloud and rainfall patterns}

Cloud classification from Meteosat Second Generation (MSG) Spinning Enhanced Visible and Infra-Red Imager (SEVIRI) provided information on the distribution of MCSs during the study. The space/time structure of rainfall associated with convective rainfall systems was determined using the EPSAT-SG (Estimation of Precipitation by SATellite Second Generation) method (details available at http://bddamma.ipsl.polytechnique.fr/statique/DIFS), providing daily accumulated rainfall over the study domain.

\subsection{Model data}

Synoptic-scale meteorological conditions were established using 6-hourly ECMWF analyses of sea level pressure, horizontal winds at 925 and $600 \mathrm{hPa}$, water vapour mixing ratio at $925 \mathrm{hPa}$, as well as subsidence at $600 \mathrm{hPa}$. It is worth noting that these analyses do have the capacity to represent convective events north of the Intertropical Convergence Zone. In addition, ECMWF analyses were used to document the meteorological conditions (winds and potential temperature) over the dust source areas as well as along a cross-section between $22^{\circ} \mathrm{N}, 20^{\circ} \mathrm{E}$ and $5^{\circ} \mathrm{N}, 10^{\circ} \mathrm{E}$, shown in Figure 1 as the dashed boxes and the dotted line, respectively.

The dust transport patterns between the source regions and the sub-Sahelian countries was assessed from back trajectory analyses using the HYSPLIT4 (HYbrid Single-Particle Lagrangian Integrated Trajectory) model (http://www.arl.noaa.gov/ready/ hysplit4.html). A total of eight isentropic back trajectories, starting at 3 and $4 \mathrm{~km}$ above ground level (agl) at several locations over West Africa, were computed every 6 hours between 9 June at 0000 UTC and 11 June at 1800 UTC. The last back trajectory ended at 1800 UTC on 14 June. The start-point altitude for the back trajectories was defined based on the airborne lidar observations (section 2.1.1). There has been some discussion of the applicability of HYSPLIT-derived back trajectories when they pass through the convective PBL, as they will presumably not account for the vertical mixing. This may be a limitation for the interpretation of the trajectories arriving in Maine-Soroa and Banizoumbou (Niger), since the PBL over northern Niger can be as deep as $5 \mathrm{~km}$. This is less critical for back trajectories further south, i.e. arriving in Ilorin, Djougou and Cotonou, as the PBL over southern Chad, Nigeria, Benin does not exceed $3 \mathrm{~km}$ amsl.

\section{Synoptic conditions between 9 and 14 June 2006}

In late spring the mean low-level circulation over North Africa is characterised by the dry northeasterly harmattan flow and the moist southwesterly monsoon flow from the Gulf of Guinea. The ITD marks the boundary between these two circulations and lies roughly above Sahel during this period. Over 9-12 June, i.e. 2-4 days prior to the field observations, sea level pressure was anomalously high over the central/eastern Mediterranean and Libyan sector driving enhanced northeasterly harmattan winds over the Niger-Chad-Sudan sector of the Sahara (not shown). This strong harmattan flow was the primary driver of dust emission in this sector, known to hold some of the most productive dust sources in West Africa, notably the Bodélé depression (in Chad). The Sudanese sources have also been reported to be particularly active in May-July, in a region extending from the western flanks of the Ethiopian highlands west to the plateaus of western Sudan and eastern Chad (Ennedi plateau), roughly between $15^{\circ} \mathrm{N}$ and $22^{\circ} \mathrm{N}$ (Prospero et al., 2002). The location of the most active Sudanese sources is shown in Figure 1.

During the field study period, prevailing meteorological conditions over Benin, southwestern Niger and the Gulf of Guinea indicate that sea level pressure gradients were rather weak over a broad region from the Gulf of Guinea to the Sahel, while a high pressure system over the Mediterranean, centred on the coasts of Tunisia and Libya dominated over North Africa. Associated with this pressure pattern a number of important circulation features are apparent

(i) At low levels (i.e. $925 \mathrm{hPa}$ ), the region of interest (i.e. Benin and surrounding countries) was under the influence of the monsoon flow and experienced rather weak winds $\left(2-6 \mathrm{~m} \mathrm{~s}^{-1}\right)$ and high moisture conditions (> $14 \mathrm{~g} \mathrm{~kg}^{-1}$, Figure 2(c,d)).

(ii) To the north, strong northerly low-level winds were seen over western Libya at $925 \mathrm{hPa}$, which were deflected around the north flank of the Hoggar towards the Atlas (Figures 1 and 2(a)).

(iii) Strong northeasterly low-level winds were also seen at 0000 UTC to blow between the Tibesti and Ennedi mountains in Chad, and over the Bodélé depression, where dust emission events are associated with an enhanced low-level jet (LLJ) feature (Washington and Todd, 2005; Washington et al., 2006; Todd et al., 2008). At 1200 UTC, the channelling of the low-level flow through the gap between the Tibesti and the Ennedi is still visible, even though much weaker than at 0000 UTC. (iv) Finally, at 0000 UTC, strong winds, in the form of a northeasterly LLJ, were observed to the east of the Ennedi and Darfur mountains, over the dust sources of west Sudan. In this area also, weaker winds were observed at 1200 UTC than at 0000 UTC.

At the longitude of Benin (roughly around $0^{\circ} \mathrm{E}$ ), the ITD was located close to the Niger-Mali border. It corresponds to the interface between the harmattan and monsoon winds, but is best seen in the water vapour mixing ratio field at $925 \mathrm{hPa}$ as separating the moist 

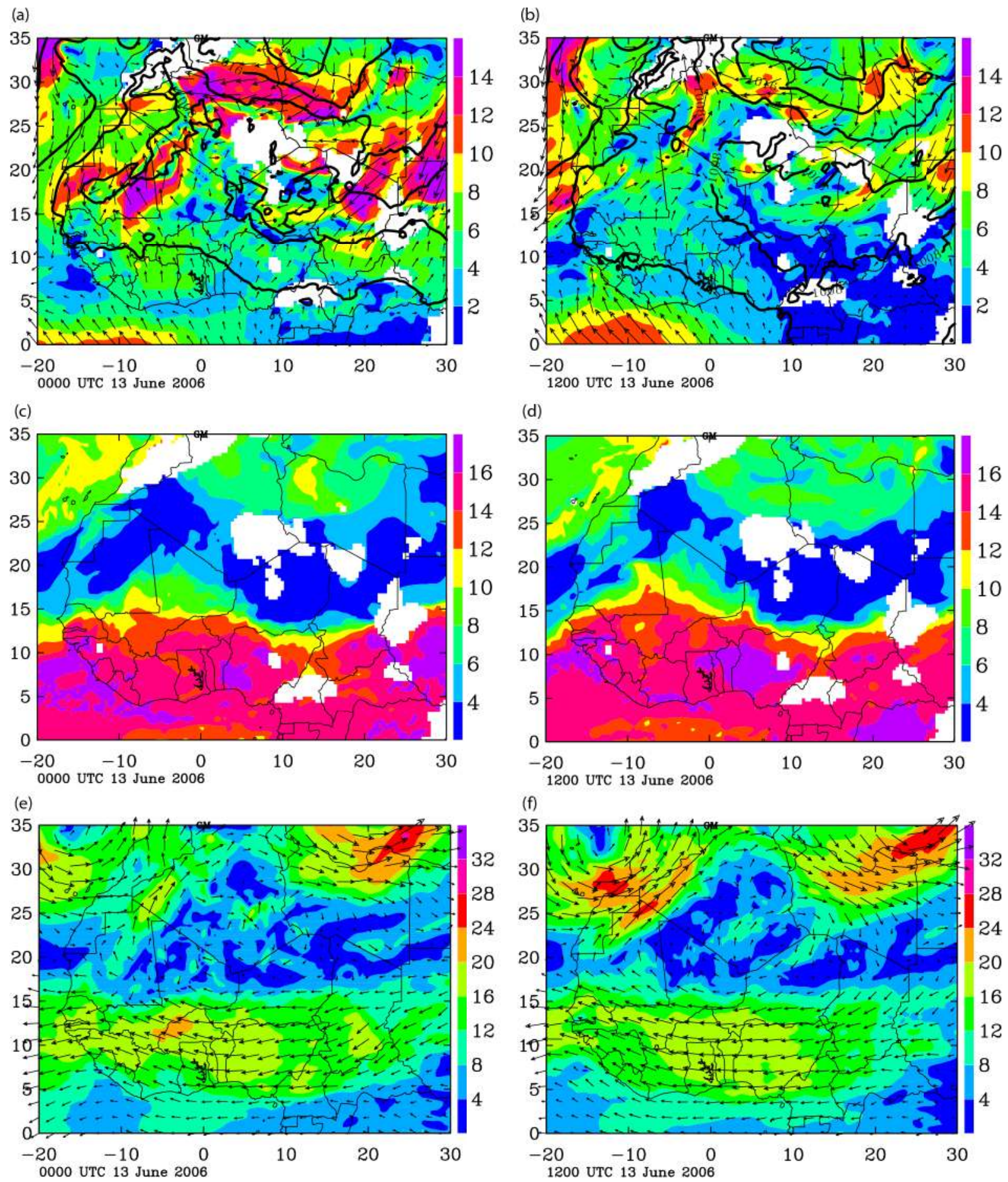

Figure 2. ECMWF analysis on 13 June 2006 at 0000 UTC (left column) and 1200 UTC (right column). (a) and (b) show wind speed (colour shading) and direction (arrows) at $925 \mathrm{hPa}$ with mean sea level pressure (thick solid contours) every $4 \mathrm{hPa}$, (c) and (d) show water vapour mixing ratio (colour shading) at $925 \mathrm{hPa}$ at $2 \mathrm{~g} \mathrm{~kg}^{-1}$ intervals, and (e) and (f) show wind speed (colour shading) and direction (arrows) at $600 \mathrm{hPa}$. This figure is available in colour online at www.interscience.wiley.com/journal/qj

monsoon flow (12 $\mathrm{g} \mathrm{kg}^{-1}$ or more) from the much drier harmattan flow $\left(8 \mathrm{~g} \mathrm{~kg}^{-1}\right.$ or less, Figure $\left.2(\mathrm{c})\right)$.

At higher levels $(600 \mathrm{hPa}$, Figure $2(\mathrm{e}, \mathrm{f}))$, the region of interest was under the influence of the AEJ which spanned from the coast of Benin to the Niger-Mali border. The AEJ intensity was moderately strong in the analyses (12$16 \mathrm{~m} \mathrm{~s}^{-1}$ ), and was present south of $15^{\circ} \mathrm{N}$ across West Africa, from Chad to Senegal.
The meteorological situation did not change significantly the next day in the analyses (not shown). Nevertheless it is worth noting that the low-level winds associated with the monsoon further weakened (below $2 \mathrm{~m} \mathrm{~s}^{-1}$ ) over most of Benin, while the AEJ at $600 \mathrm{hPa}$ intensified slightly. The position of the ITD around $0^{\circ} \mathrm{E}$ migrated south (but remained over Niger) as the result of a wind surge from the northeast coming from the Atlantic 
Ocean merging with flow coming from the southeast around the continent and penetrating over Senegal.

Overall, the meteorological situation during 9-12 June 2006 was very similar to that on 13 June, with the notable exception of the strength of the LLJs observed over Bodélé and West Sudan. (This point is further discussed in section 4.1.)

\section{Regional distribution of aerosols from 9 to 14 June 2006: Emission, transport and scavenging}

During the period from 9 to 14 June 2006, satellite data indicate that numerous dust source were active (Figure 3). Of particular interest to this study are the high OMI AI values observed over (i) Chad and nearby Niger (9-12 June) which have previously been shown to be connected to strong dust outbreaks in the Bodélé depression area (e.g. Prospero et al., 2002; Washington et al., 2003) and (ii) regions of northern Sudan (9 and 10 June) to the east. ECMWF analyses for that period suggests these large AI values were connected to strong nocturnal low-level winds (section 3). The largest aerosol loads (as derived from OMI AI) are observed over the eastern part of the domain (i.e. east of Niger) on 9 June. The aerosol load appears to progressively advected westward between 9 and 14 June, the OMI-derived AI showing relatively low values over Benin, eastern Niger, Chad and Sudan on 14 June.

OMI AI fields are known to be sensitive to dust load, as well as the altitude at which the dust is transported. Difficulties in interpretation of the AI fields also arise in the presence of clouds; inadequate screening may result in unrealistically low AI values. Nevertheless, the daily evolution of the AI values is found to be quite consistent with that of the AOD measurements derived from sun-photometers located in Maine-Soroa and Banizoumbou (Figure 4(a,b)) as well as Djougou and Ilorin (Figure $4(\mathrm{c}, \mathrm{d})$ ), i.e. further downstream of the Bodélé and Sudan dust sources. It is also found to be consistent with the AOD measurements derived from MODIS around midday in Banizoumbou, Djougou and Ilorin. Note that in Figure 4, satellite products are plotted (a)
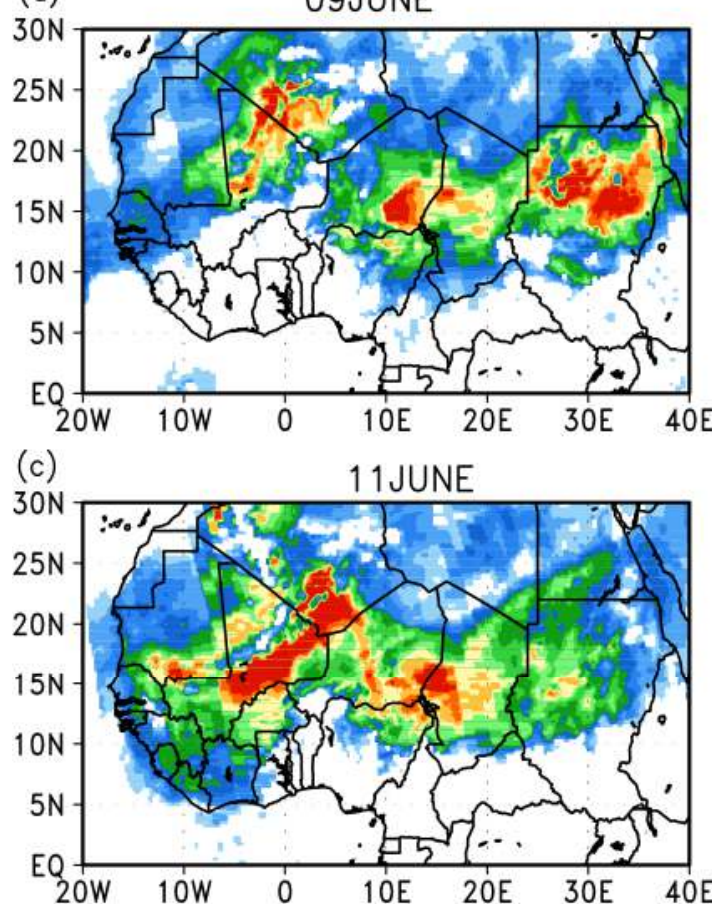

(e)

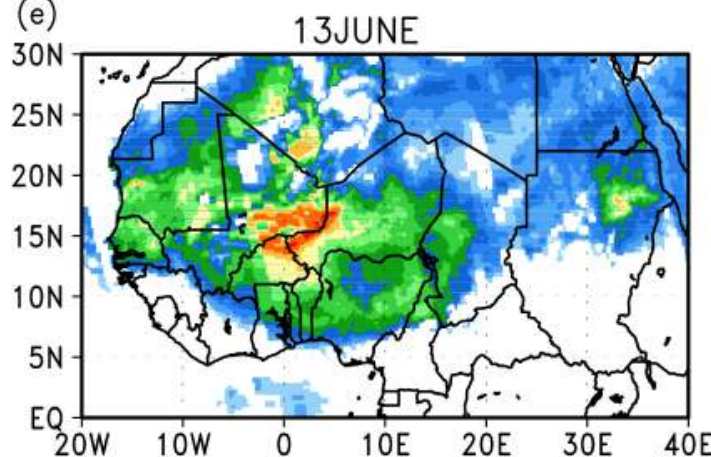

(b)

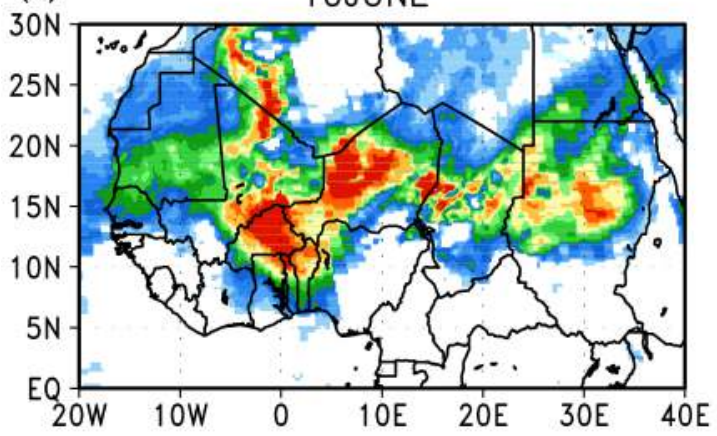

(d)

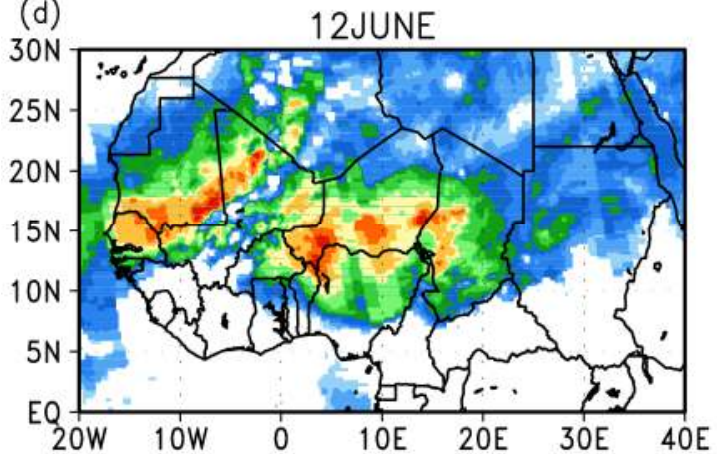

(f)

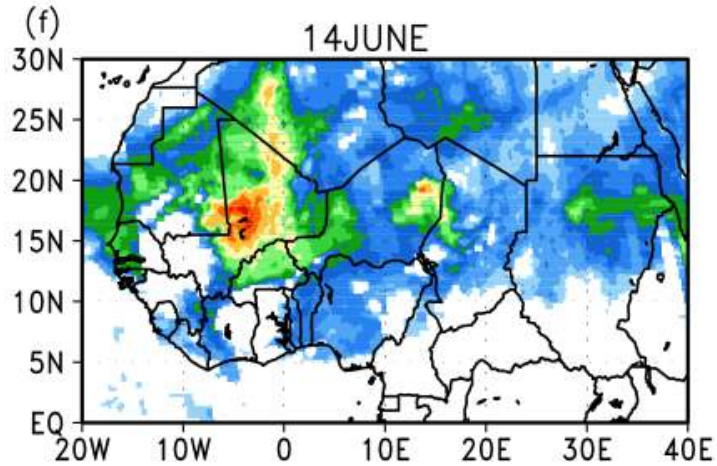

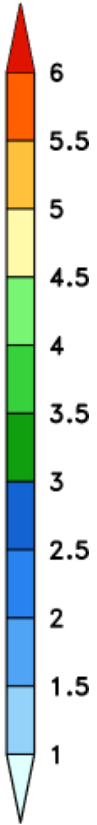

5.5

5

4.5

3.5

2.5

1.5

$\sqrt{1}$

Figure 3. Daily OMI Aerosol Index distribution over West Africa from 9 to 14 June 2006, around 1300 UTC. This figure is available in colour online at www.interscience.wiley.com/journal/qj 

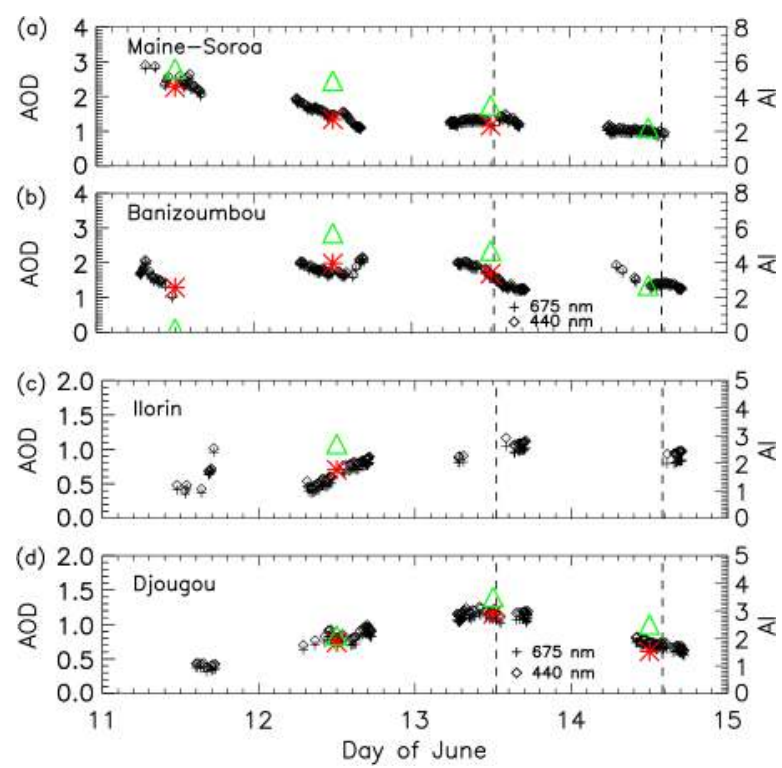

Figure 4. Aerosol optical depth at $440 \mathrm{~nm}$ (diamonds) and $670 \mathrm{~nm}$ (crosses) derived from sun-photometer measurements in Sahel, namely (a) Maine-Soroa and (b) Banizoumbou, Niger, and in sub-Sahel, namely (b) Ilorin, Nigeria and (d) Djougou, Benin, between 11 June at 0000 UTC and 15 June 2006 at 0000 UTC. The green triangles represent the daily averaged OMI-derived AI values extracted at the location of the sun-photometer sites. The red asterisks represent the daily MODIS-derived AOD at $550 \mathrm{~nm}$ from the Deep Blue Collection 005 (Maine-Soroa and Banizoumbou) and from the AQUA Collection 005 (Djougou and Ilorin). The dashed lines represent the average time of the F/F20 overpasses on 13 and 14 June in Djougou. Note that satellite products are plotted only when AERONET level 2 retrievals exist (in the absence of clouds). This figure is available in colour online at www.interscience.wiley.com/journal/qj

only when AERONET level 2 retrievals exist (i.e. in the absence of clouds).

In the following, we analyse the processes likely to affect the dust load (and resulting AOD and AI fields) over Benin and southwestern Niger, namely the variability of the emissions over Bodélé and Sudan, the transport patterns and the scavenging in connection with the life cycle of MCSs travelling across West Africa during 9-14 June.

4.1. Temporal evolution of the dust loads in the Bodélé and Sudanese regions

The temporal evolution of the dust load over the Bodélé region and over Sudan (which is linked to emissions and eventually controls the dust mass flux transported over Benin) has been investigated using daily MODIS Deep Blue AODs between 9 and 15 June 2006 (around 1330 UTC) over three domains (Figure 5(a)): one including the Bodélé depression $\left(16-18^{\circ} \mathrm{N}, 16-19^{\circ} \mathrm{E}\right)$, and two over Sudan, one including the western sources $\left(16-21^{\circ} \mathrm{N}\right.$, $\left.25-30^{\circ} \mathrm{E}\right)$ and one including the eastern sources (16$\left.21^{\circ} \mathrm{N}, 30-36^{\circ} \mathrm{E}\right)$.

Overall, the AOD over the Bodélé region exhibited a diminishing trend between 9 and 13 June, from 2.61 to 0.65 (Figure 5(a)). (Recall there are no AOD available on 14 June.) As discussed previously, this is linked to the decrease in strength of the nocturnal low-level winds
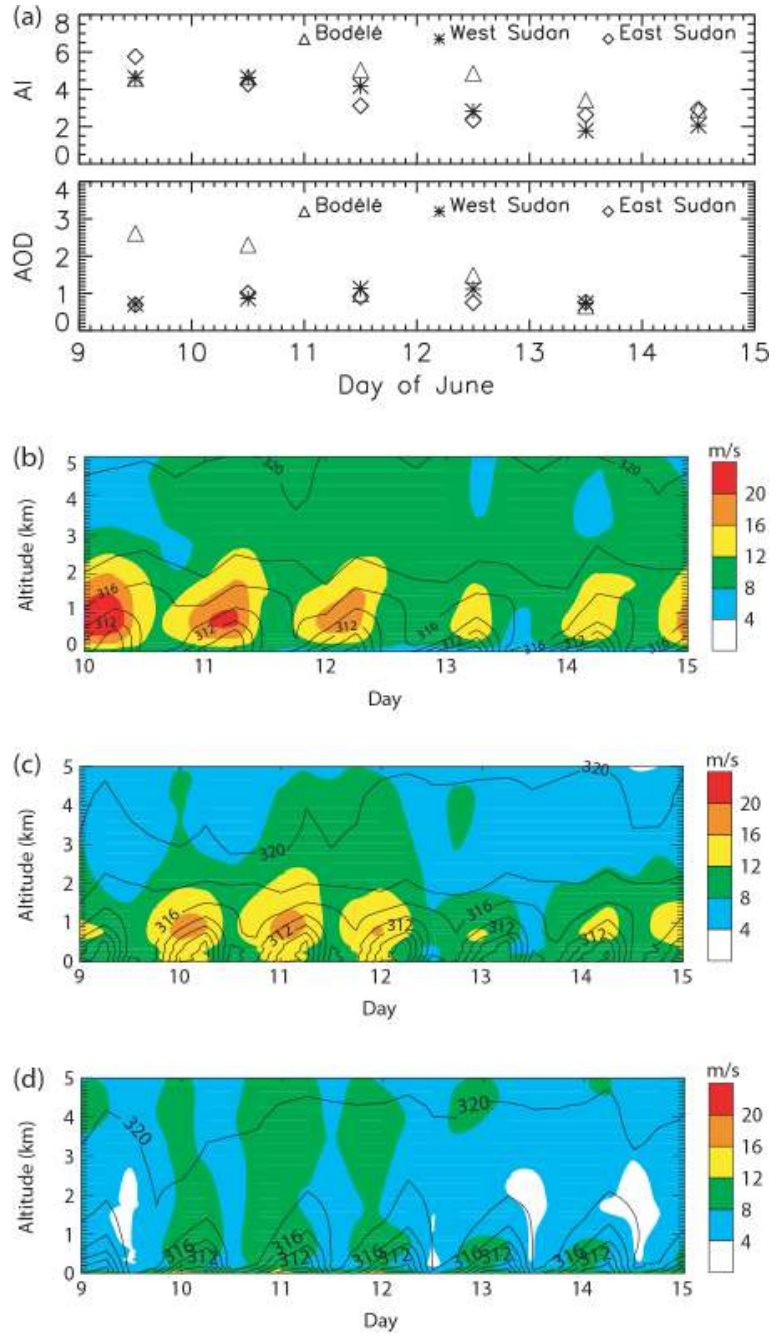

Figure 5. (a) The upper panel shows the temporal evolution, between 9 June 0000 UTC and 15 June 0000 UTC, of the OMI AI over the Bodélé depression area $\left(16-18^{\circ} \mathrm{N}, 16-19^{\circ} \mathrm{E}\right)$ shown as triangles, western Sudan $\left(16-21^{\circ} \mathrm{N}, 25-30^{\circ} \mathrm{E}\right)$ shown as asterisks, and eastern Sudan $\left(16-21^{\circ} \mathrm{N}\right.$, $30-36^{\circ} \mathrm{E}$ ) shown as diamonds. The lower panel is as the upper panel, but for MODIS AOD from the Deep Blue Collection 005. (b) Timealtitude cross-section of horizontal wind speed (colour) and isentropes (contours) for the same period, derived from ECMWF analyses over domain $16-18^{\circ} \mathrm{N}, 16-19^{\circ} \mathrm{E}$ (Bodélé). (c) is as (b), but for the domain $16-21^{\circ} \mathrm{N}, 25-30^{\circ} \mathrm{E}$ (western Sudan). (d) is as (b), but for the domain $16-21^{\circ} \mathrm{N}, 30-36^{\circ} \mathrm{E}$ (eastern Sudan). This figure is available in colour online at www.interscience.wiley.com/journal/qj

blowing over the area during the previous night, as seen in the ECMWF analyses (at 0600 UTC, not shown). It has been well established (e.g. Washington and Todd, 2005) that dust emission from the Bodélé is related to surface wind speed maxima which occur in the hours after sunrise. This phase shift in the diurnal cycle of the LLJ and surface winds is associated the downward transfer of momentum from the nocturnal LLJ to the surface due to turbulent mixing after solar heating commences each day (Todd et al., 2008).

The AOD over West Sudan increased from 9 to 12 June (from 0.72 to 1.13 ), and decreased afterwards to 0.73 (Figure 5(a)). This evolution also appears well correlated with the temporal evolution of the strength of the lowlevel winds blowing over west Sudan during the previous 
night, as seen in the ECMWF analyses (Figure 5(c)). A similar behaviour was observed over east Sudan, with an AOD increasing from 0.70 to 1.0 between 9 and 11 June, and decreasing to 0.75 afterwards (Figure 5(a)). The nocturnal LLJ was weak over east Sudan during this period (Figure 5(d)), but peaked during the night from 10 to 11 June (as over west Sudan). The linear Pearson correlation coefficient between the averaged $925 \mathrm{hPa}$ winds extracted from the ECMWF analyses at 0600 UTC and the MODIS Deep Blue derived AODs around midday the same day is equal to $0.87,0.89$ and 0.94 , over the Bodélé, west Sudan and east Sudan regions, respectively.
It is worth noting that over 9-14 June the temporal evolution of daily OMI-derived AIs (also observed around midday, Figure 3 ) for each of the identified source regions is not as consistent with the temporal evolution of daily MODIS AODs values as it is further downstream (especially over Sudan), as is (for instance) evident from the comparison shown in Figure 4. This can be partly explained by the fact that AIs may be biased towards dust which is elevated, thereby explaining the better agreement away from the sources, once dust has been mixed through the depth of the PBL. The linear Pearson correlation coefficient between the averaged $925 \mathrm{hPa}$ winds extracted from the ECMWF analyses at 0600 UTC and
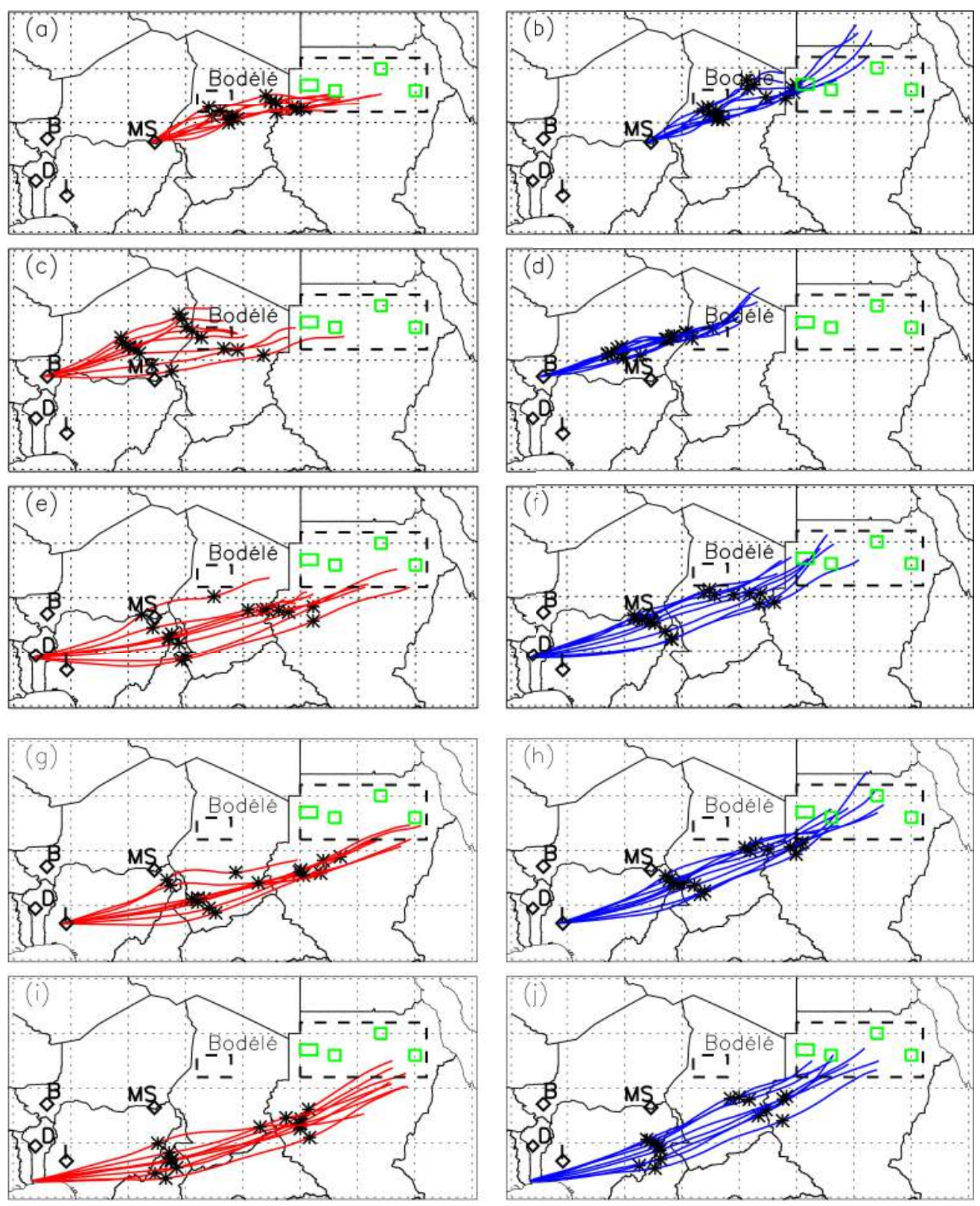

Figure 6. Isentropic back trajectories starting at $3000 \mathrm{~m}$ agl (solid blue lines) and $4000 \mathrm{~m}$ agl (solid red lines) at (a,b) Maine-Soroa, (c, d) Banizoumbou, (e,f) Djougou, (g, h) Ilorin and (i,j) Cotonou. A total of eight 3-day back trajectories were computed using the HYSPLIT model, starting every 6 hours between 0000 UTC on 10 June and 1800 UTC on 11 June. The last back trajectory ended at 1800 UTC on 14 June. The asterisks along the trajectories indicate the positions of the air mass every 24 hours. The two dashed boxes represent the Bodélé and broad Sudanese source regions. The solid green boxes within the Sudanese box correspond to the sources described in Prospero et al. (2002); see text for details. This figure is available in colour online at www.interscience.wiley.com/journal/qj 
the OMI derived AIs around midday the same day is equal to $0.62,0.70$ and -0.32 , over the Bodélé, west Sudan and east Sudan regions, respectively.

In summary, it appears that the Sudanese and Bodélé sources were active during the four days preceeding the aircraft operations on 13 and 14 June. AODs over Sudan remained smaller than 1.15 during the period. AODs over the Bodélé area were almost a factor of 4 (2.5) greater than over Sudan on 9 June (10 June), but were of the order of those observed over Sudan during the rest of the period.

\subsection{Transport patterns from the source regions}

For the entire period, back trajectories starting at $3 \mathrm{~km}$ agl (the approximate height of the dust layer as determined by lidar) suggest that air masses sampled along the flight track over Niger had travelled over the Bodélé region in the previous 2.5 to 3 days (Figure $6(\mathrm{~d})$ ). On the other hand, the air masses sampled over Benin were coming from further east, i.e. from Sudan (Figure 6(f,j)).

A similar behaviour was obtained for the back trajectories ending at $4 \mathrm{~km}$ agl, even though the west Sudan sources appear also to influence the composition of the air mass over southwest Niger (Figure 6(c)). At this altitude also, back trajectories suggest that the air masses over Djougou and Cotonou were coming from even further east than at $3 \mathrm{~km}$ agl, i.e. from east Sudan.

Back trajectories also suggest that the Darfur and Ennedi mountains played a key role in lifting the dustladen air masses from the Sudanese sources to altitudes where they could be transported westward into the AEJ, and over Benin (not shown). The mechanisms for lifting the dust originating from the Bodélé depression was found to be quite different, as no outstanding orographic features could provide the lifting. Instead, the lifting was found to occur at the ITD and to be related to the presence of the cooler more stable monsoon, forcing the hotter and drier Saharan air to ascend. Vertical cross-sections (extracted from ECMWF analyses) going through the pass between the Tibesti and the Ennedi (dashed line in Figure 1), and roughly aligned with the direction of the LLJ are shown (Figure 7). They suggest that during the night (0000 UTC), the strong near-surface winds blowing over Bodélé (between $16^{\circ}$ and $18^{\circ} \mathrm{N}$ ) were forced to flow over the impinging monsoon around $15^{\circ} \mathrm{N}$, thereby lifting dust-laden air masses along isentropes to altitudes of $2.5 \mathrm{~km}$ amsl and higher, which are in turn caught in the AEJ circulation and transported over Nigeria, Benin and Ghana (Figure 7(a)). At 1200 UTC, mixing in the convective PBL over a greater depth than in the morning and the marked northeasterly winds (Figure 7(b)) may also have transported dust aerosols southward, over the monsoon flow, and into the region of the AEJ (Figure 2(f)). Indeed, the daytime PBL development that follows the nocturnal LLJ is a key mechanism that results in a diurnal cycle in the uplift and vertical transport of dust (e.g. Chaboureau et al., 2007)

In summary, it appears that the dust observed over Benin and southwest Niger on 13-14 June was mobilized
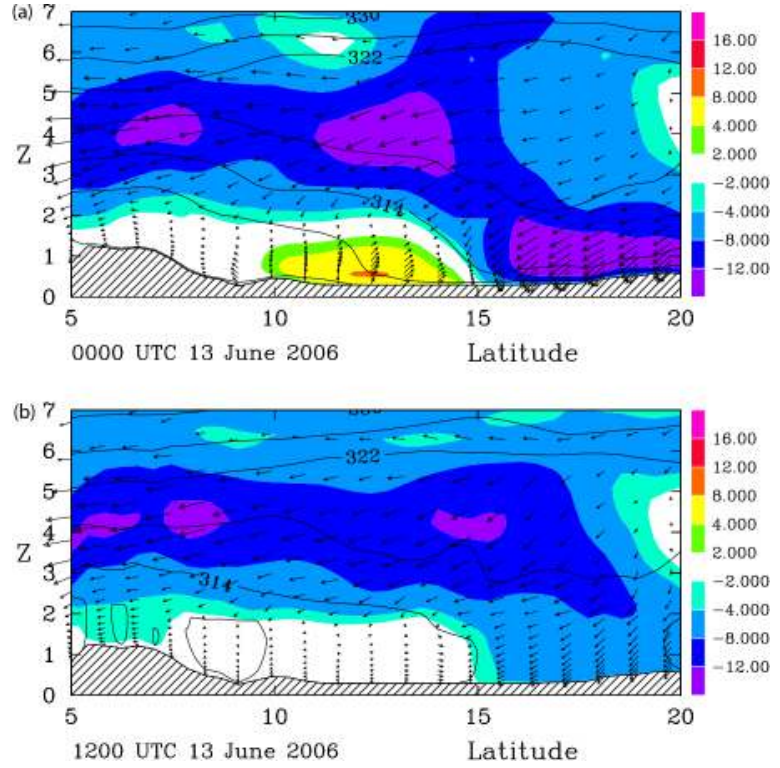

Figure 7. Vertical cross-sections (latitude-altitude) of tangent component of the ECMWF wind between $5^{\circ} \mathrm{N}, 10^{\circ} \mathrm{E}$ and $20^{\circ} \mathrm{N}, 22^{\circ} \mathrm{E}$ on 13 June 2006 at (a) 0000 UTC and (b) 1200 UTC. This figure is available in colour online at www.interscience.wiley.com/journal/qj

in the three days preceeding the field mission (i.e. primarily on 10-11 June). Within a day, this dust was forced to rise over obstacles (either orography or the monsoon flow) and became available for long-range transport by the AEJ.

\subsection{Regional aspects of the MCS rainfall patterns}

During the period of interest, several MCSs were observed to be triggered east of Benin, over the Jos plateau (Nigeria), the Darfur mountains (Sudan) or over the Ethiopians highlands. The signature of the MCSs in terms of rainfall, as obtained with the EPSAT-SG method, is shown in Figure 8.

Based on the back trajectory analyses (section 4.2), we shall analyse the potential impact of precipitation during 11-13 June (12-14 June) on the air masses arriving over the AERONET stations on 13 June (14 June).

From Figure 8, it can seen that air masses travelling between the dust sources and Banizoumbou and MaineSoroa (southern Niger) are likely not impacted by wet scavenging during the entire period.

For air masses arriving in Ilorin, Djougou and Cotounou (southern Nigeria and Benin) on 13 June at 1200 UTC (roughly the time of the airborne operations), precipitation data are analysed over three days, between 1200 UTC on a given day and 1200 UTC on the next day. Back trajectories suggest that between 1200 UTC on 10 June and 1200 UTC on 11 June (day 3), aerosol-laden air masses from the source region remained over western Sudan and eastern Chad, i.e. mostly clear from the heavy rain over the Central African Republic (Figure 8(a)). The following day (day 2 of the back trajectories, between 1200 UTC on 11 June and 1200 UTC on 12 June), air masses travelled across Chad, entering Nigeria and 
(a)

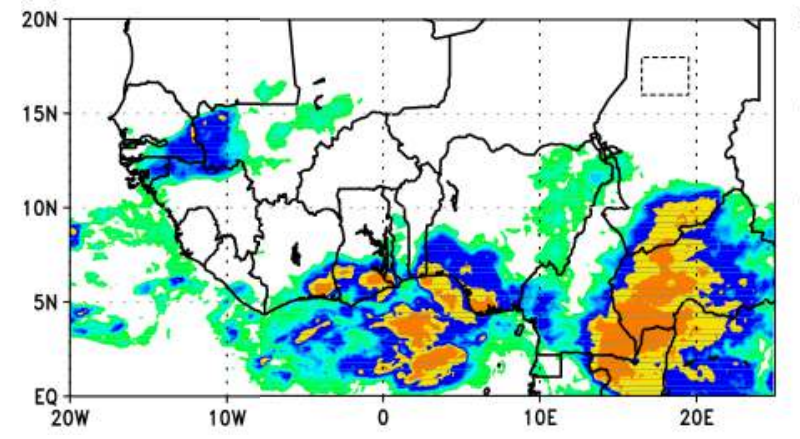

(b)

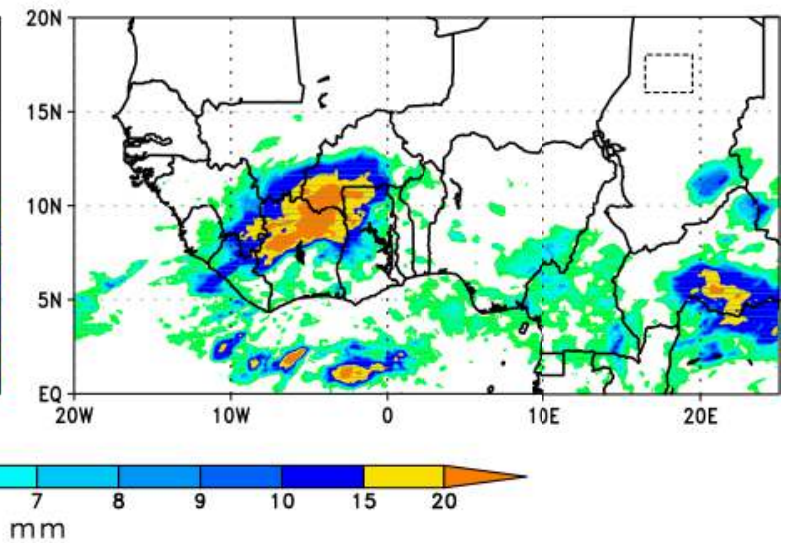

(d)

(c)

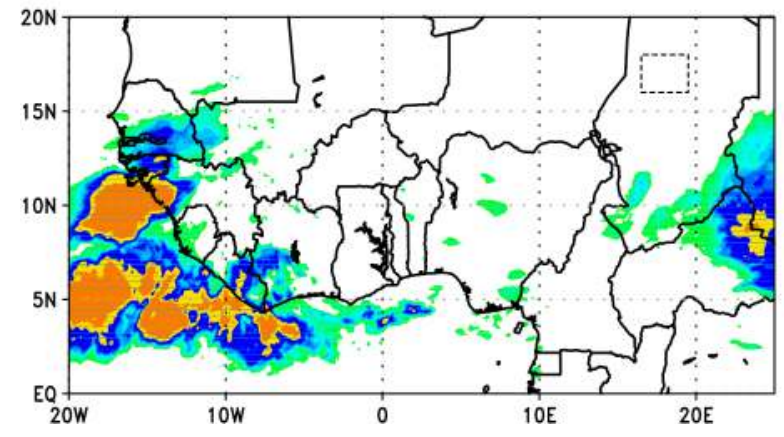

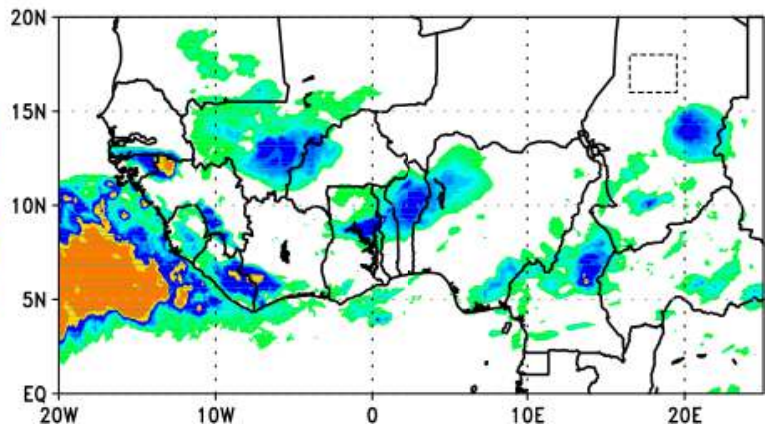

Figure 8. EPSAT-SG-derived 24-hour accumulated rainfall (mm) (a) from 1200 UTC on 10 June, (b) from 1200 UTC on 11 June, (c) from 1200 UTC on 12 June and (d) from 1200 UTC on 13 June. The dashed line box represents the Bodélé source region. This figure is available in colour online at www.interscience.wiley.com/journal/qj

Cameroon in mostly rain-free conditions (Figure 8(b)). Finally, between 1200 UTC on 12 June and 1200 UTC on 13 June (day 1), air masses travelled across Nigeria into Benin in rain-free conditions (Figure 8(c)).

A similar analysis was conducted for air masses arriving in Ilorin, Djougou and Cotounou at 1200 UTC on 14 June. Back trajectories suggest that on day 3 (between 1200 UTC on 11 June and 1200 UTC on 12 June) air masses travelling from the source region at $4 \mathrm{~km}$ agl perhaps experienced weak precipitation over southern Sudan (Figure 8(b)). On day 2 (between 1200 UTC on 12 June and 1200 UTC on 13 June), air masses travelled over Chad in nearly rain-free conditions (Figure 8(c)). Finally on day 1 (between 1200 UTC on 13 June and 1200 UTC on 14 June), only air masses arriving at Djougou and perhaps Ilorin may have experienced moderate rain associated with a convective system travelling over northwestern Nigeria and Benin during the night of 13-14 June. (Figure 8(d)). Nevertheless, this is difficult to assess using back trajectories based on global meteorological analyses (i.e. NCEP analyses) in which the deep convection is parametrized. Furthermore, back trajectories suggest that 24 hours prior to their arrival over Djougou at 1200 UTC on 14 June, air masses were close to the Chad-Nigeria border, i.e. well east of the MCS initiation region. Hence, since the MCS propagated at a speed comparable to that of the winds in the AEJ core, wet scavenging may never have affected air masses located to the east of the region of initiation.
In summary, it is very likely that the dust load transported in the AEJ for air masses arriving over Benin, western Nigeria and southern Niger around midday on 13 and 14 June were not significantly impacted by wet scavenging (e.g. rain interception of aerosols) occurring east of and over Benin.

\subsection{Discussion}

The above analysis suggests that during 11-14 June the temporal evolution of the dust load observed over the AERONET stations close to the region of aircraft operation on 13-14 June should roughly follow that of the dust load observed over the source regions, with a lag of three days on average. However, establishing a relationship between the two is not straightforward due to the fact that the dust load observed over a station may be under the influence of more than one source, and because dust may also be mobilized locally (in connection with the diurnal cycle of surface wind speed, as for example in Banizoumbou).

Based on the fact that air masses reaching the MaineSoroa, Banizoumbou and Ilorin AERONET stations during 11-14 June did not experience any scavenging by rain, we may conclude that the decrease in AOD over southern Niger between 13 and 14 June (Figure 4(a,b)), AODs were observed around midday), most likely results from a reduction of the emissions in the source regions (Figure 5(a)). For instance, in Maine-Soroa, which is 
mainly under the influence of the Bodélé source region, a reduction of AOD is consistent with the decrease of AOD observed one day earlier (as suggested by back trajectories, Figure 6(a,b)) over Bodélé (i.e. between 12 and 13 June). Similarly, Banizoumbou appears to be under the influence of both Bodélé and west Sudan, to a smaller extent. The decrease of AOD could be related to the substantial decrease in AOD observed over Bodélé three days earlier (as suggested by back trajectories, Figure 6(c,d)), i.e. between 10 and 11 June. The fact that AODs in Ilorin decreased slightly between 13 and 14 June, while AODs over Sudan increased slightly between 10 and 11 June, may just be the result of dry deposition of the largest dust particles during the three days of transport.

Interestingly, a more pronounced decrease in AOD between 13 June and 14 June was observed in Djougou than at the other stations (Figure 4(d)), while AODs over Sudan increased slightly between 10 and 11 June. This is likely caused by processes other than just dry deposition. For the reasons detailed in section 4.3, it is thought to be related to dynamical and thermodynamical processes in the wake of the 13-14 June overnight MCS, rather than wet scavenging. We now examine its structure and life cycle in more detail to obtain further insight into the MCS impact on the dust load and distribution over Djougou.

\section{The 13-14 June MCS over Benin}

On 13 June, an MCS initially developed in the vicinity of the Jos plateau, in Nigeria (around 1600 UTC). It developed rapidly while remaining stationary until 2000 UTC $\left(12^{\circ} \mathrm{N}, 5^{\circ} \mathrm{E}\right.$; Figure 9(a)). From 2000 UTC onwards, the MCS propagated west and reached the
Benin-Nigeria border around 0000 UTC on 14 June (Figure 9(b)). The convective part of the MCS was over Benin between 0000 and 0400 UTC (Figure 9(b, c)). The MCS produced moderate precipitation along its trajectory as shown in Figure 8(d). The MCS then travelled over Benin, Togo and Ghana during the morning hours of 14 June (Figure 9(d)). The largest rain amounts on that day were observed over Benin (Figure 8(d)). The meteorological station at Djougou reported the arrival of rain shortly after 0200 UTC. The largest rain amounts were observed between 0200 and 0300 UTC $(\approx 7 \mathrm{~mm})$, while much smaller amounts were observed afterwards to be associated with the stratiform clouds trailing the MCS.

Several mechanisms are likely to affect the dust load and vertical distribution over Benin and southwestern Niger in connection with the MCS. Dust mobilisation occurring at the leading edge of the MCS cold pools is not expected to be a factor over Benin because the surface is mostly vegetated, but could play role over southwestern Niger (e.g. Flamant et al., 2007). In the convective region, rain interception of aerosols in the cool downdraught of the MCS (where precipitation is generally abundant) mostly washes out aerosols from the PBL. On the other hand, aerosols in the upper SAL may be scavenged due to the stratiform rain. Furthermore, widespread subsidence below the stratiform cloud deck and in the wake of an MCS can also modify their vertical distribution. Finally, soil moisture patterns in the wake of the MCS may induce mesoscale atmospheric circulations (e.g. Taylor et al., 2007) that, in turn, may impact on the horizontal as well as the vertical distribution of dust in the lowest few kilometres by affecting the exchange processes between the PBL and the SAL. However, a detailed analysis of (a)

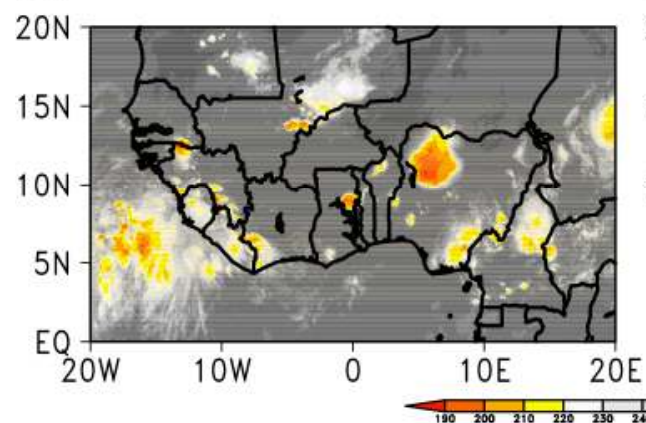

(b)

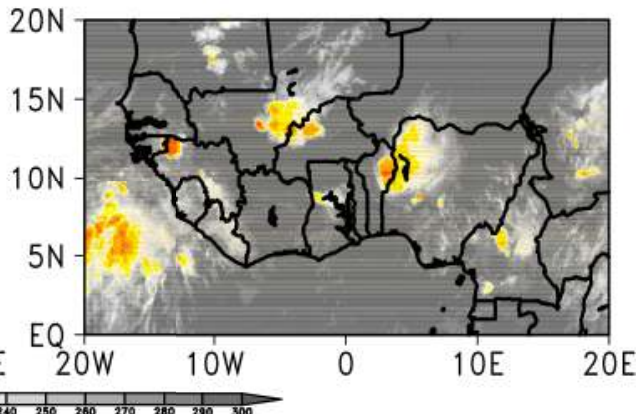

(d)

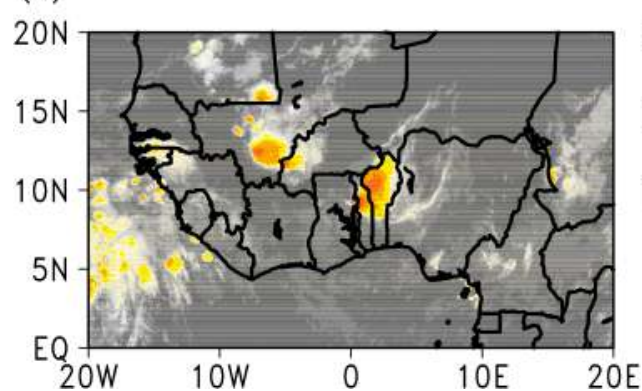

$20 \mathrm{~N}$

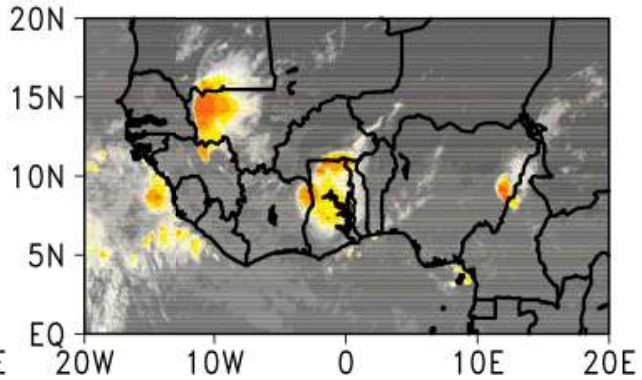

Figure 9. MSG SEVIRI $10.8 \mu \mathrm{m}$ images (K) at (a) 2000 UTC on 13 June, and on 14 June at (b) 0000 , (c) 0400 and (d) 1000 UTC. This figure is available in colour online at www.interscience.wiley.com/journal/qj 

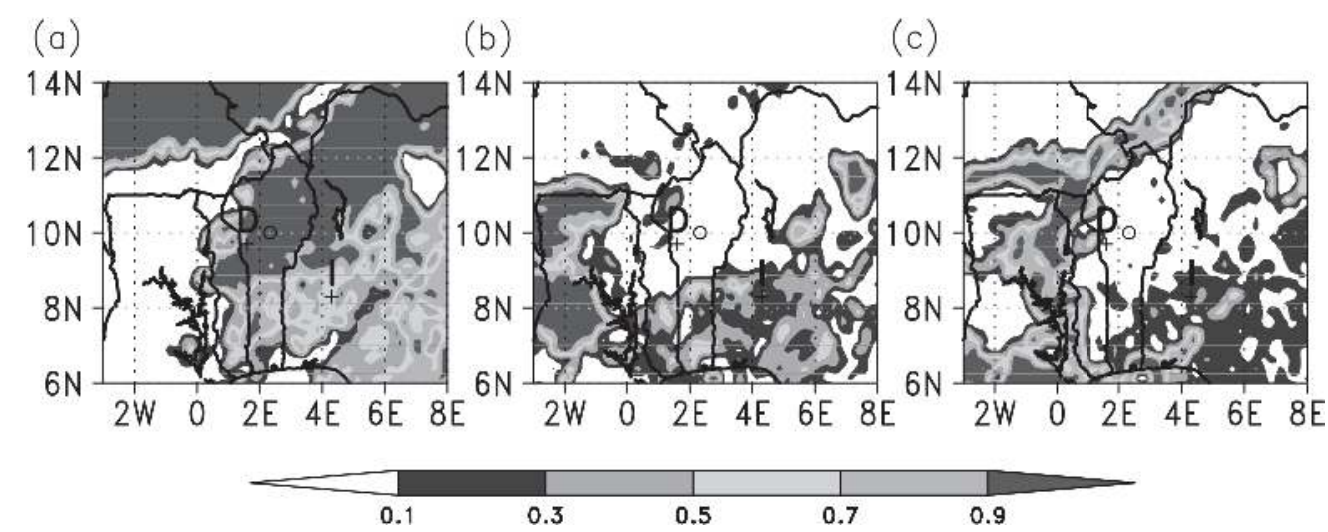

Figure 10. MSG/SEVERI cloud classification over West Africa at 1400 UTC on 14 June showing the fraction of (a) clear skies, (b) low-level opaque clouds and (c) elevated semi-transparent clouds. D and I denote Djougou and Ilorin, respectively. The circle indicates the position of the dropsonde released from the F/F20 on 14 June (data shown in Figure 15).

the influence of each of these mechanisms on the dust load and distribution is beyond the scope of this paper, essentially due to the lack of adequate observations in the vicinity of the MCS. Nevertheless, some of the spaceborne observations described herein do provide insights into these processes, for the interpretation of the airborne lidar and dropsonde data acquired after the passage of the MCS which are analysed in section 6 .

For instance, an indication of the regional extent of the subsidence in the wake of the MCS is given by the MSG/SEVERI cloud classification on 14 June at 1400 UTC (Figure 10(a)). To some extent, this is confirmed by the subsidence patterns from ECMWF at $600 \mathrm{hPa}$ (Figure 11), in which the signature of this storm is seen. ECMWF analysis suggest ascending motions at $600 \mathrm{hPa}$ on 13 June over most of Benin (Figure 11(a)), while strong subsiding motions are seen in the wake of the MCS on 14 June at 1200 UTC (Figure 11(b)). Southern Niger, northern Benin as well as northwestern Nigeria (i.e. along the track of the MCS) were mostly cloud-free

(a)

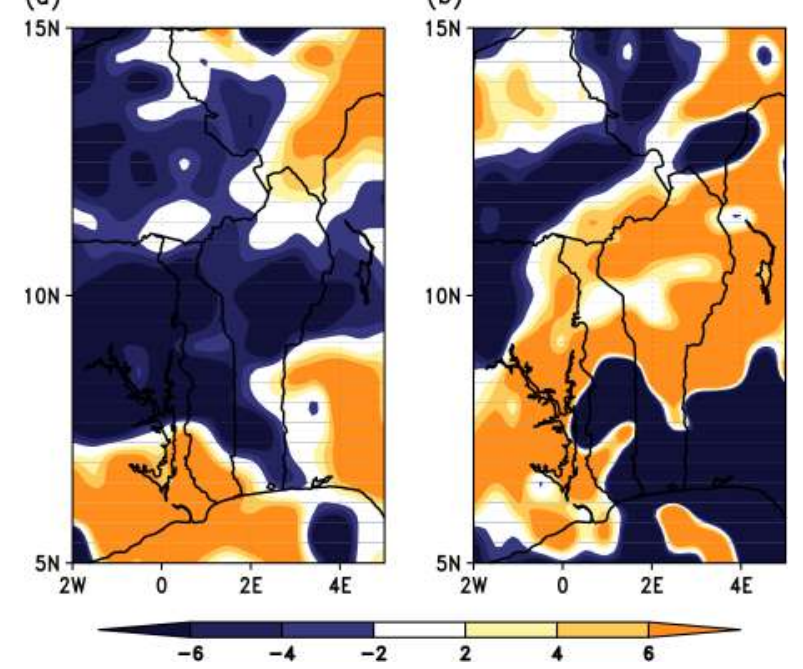

Figure 11. ECMWF-derived subsidence at $600 \mathrm{hPa}\left(\mathrm{Pa} \mathrm{s} \mathrm{s}^{-1}\right)$ over Benin and surrounding countries at 1200 UTC on (a) 13 June and (b) 14 June. This figure is available in colour online at www.interscience.wiley.com/journal/qj at the time of the F/F20 overpass on 14 June (Figure 10(a)). This suggests that MCS-related subsidence may have impacted on the vertical structure of the dust plume over northern Benin and southern Niger. This also suggests that the dust plume was not subject to scavenging by stratiform rain along the MCS track because processed air masses were replaced by fresh dust transported in the upper Saharan aerosol layer by the AEJ, i.e. roughly at the same speed as the MCS. The Ilorin AERONET station was also seen to be located in the area covered by low-level opaque clouds (Figure 10(b)), consistently with the fact that no level 2 AERONET products were available in Ilorin at the time of the aircraft operations (Figure 4). In addition, the precipitation associated with the propagating MCS was observed to have an impact on the soil moisture/temperature in the early afternoon on 14 June (not shown). A sharp northeastsouthwest oriented gradient in soil moisture/temperature was observed over northern Benin, with dry/hot surfaces to the north and moist/cool surfaces to the south. At the longitude of the aircraft track on 14 June, the gradient is located close to $10^{\circ} \mathrm{N}$, and the influence of related mesoscale atmospheric circulations is expected to be observed in the airborne data in this region.

\section{The vertical distribution of dust over southern Niger and Benin on 13 and 14 June}

We now analyse the vertical distribution of the dust from Bodélé and Sudan over southern Niger and Benin, using airborne lidar measurements. We discuss the impact of MCS on the vertical distribution of dust by comparing airborne lidar observations before and after the passage of the MCS over Benin. This is complemented by an analysis of space-borne lidar observations acquired over eastern Niger and Nigeria as well as western Chad (Figure 1).

6.1. Vertical distribution of dust prior to the passage of the MCS

Eleven out of the twelve dropsondes released during the 13 June flight (Table I) were used to construct 

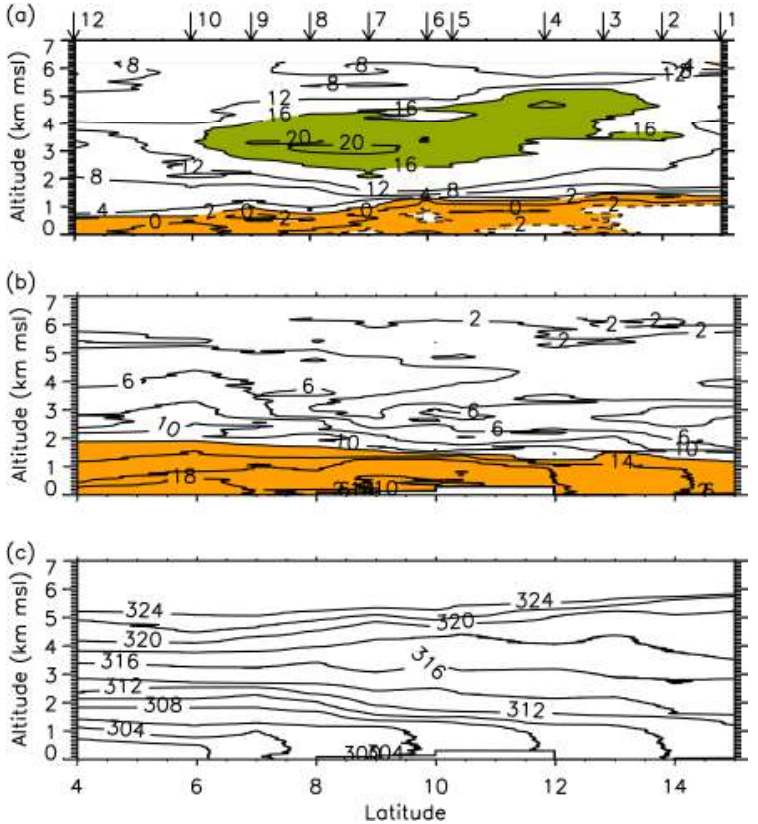

Figure 12. Dropsonde-derived vertical cross-sections of (a) the wind component perpendicular to the F/F20 track, (b) water vapour mixing ratio and (c) potential temperature between 1137 and 1328 UTC on 13 June 2006. The wind component perpendicular to the flight track is contoured every $2 \mathrm{~m} \mathrm{~s}^{-1}$. In (a), positive (negative) velocity values and solid (dashed) lines are indicative of a flow entering (exiting) the crosssection. The orange area indicates where the wind speed is between -2 and $+2 \mathrm{~m} \mathrm{~s}^{-1}$. The green area indicates where the wind speed exceeds $16 \mathrm{~m} \mathrm{~s}^{-1}$ (i.e. the AEJ). In (b), the contour interval is $1 \mathrm{~g} \mathrm{~kg}^{-1}$ below $6 \mathrm{~g} \mathrm{~kg}^{-1}$, and $2 \mathrm{~g} \mathrm{~kg}^{-1}$ above. The orange area indicates where water vapour mixing ratio exceeds $12 \mathrm{~g} \mathrm{~kg}^{-1}$ (i.e. the monsoon flow). In (c), the contour interval is $1 \mathrm{~K}$. The arrows indicate the location of the dropsonde released along the transect. The numbers refer to the dropsondes as they appear in Table I. This figure is available in colour online at www.interscience.wiley.com/journal/qj

the two-dimensional cross-sections shown in Figure 12 The dominant dynamical feature along the transect was observed to be the AEJ, as seen in the wind field component perpendicular to the track (Figure 12(a)). Weak winds were observed to be associated with a shallow monsoon flow (westerly component less than $\left.2 \mathrm{~m} \mathrm{~s}^{-1}\right)$. A large wind shear $\left(14 \times 10^{-3} \mathrm{~s}^{-1}\right.$ over a $1 \mathrm{~km}$ depth) was observed over the monsoon flow in the central part of the leg. Weak meridional winds were observed throughout the lower troposphere along the transect (not shown). The monsoon flow was characterized by large water vapour mixing ratios (greater than $12 \mathrm{~g} \mathrm{~kg}^{-1}$, Figure 12(b)), whereas the AEJ was characterized by values ranging between 2 and $6 \mathrm{~g} \mathrm{~kg}^{-1}$. The monsoon flow was observed all along the flight track, consistent with the ECMWF analysis at 1200 UTC on 13 June (Figure 2). The shallow monsoon flow was well mixed below $1 \mathrm{~km}$ amsl (Figure 12(c)). Very stable conditions were observed above the monsoon flow to the south of $8^{\circ} \mathrm{N}$. Further north, the vertical gradient of potential temperature was observed to increase with increasing latitude, as the result of strong mixing in the PBL in the northern Sahel and the Sahara. These are canonical conditions for the existence of the AEJ (e.g. Thorncroft et al., 2003; Parker et al., 2005).

On 13 June, LEANDRE 2 ABC measurements evidenced the presence of an extended and thick dust plume spanning from north of Niamey $\left(15^{\circ} \mathrm{N}\right)$ to the Benin coastline $\left(6^{\circ} \mathrm{N}\right)$ (Figure 13(a)). The depth of the plume was of the order of $3 \mathrm{~km}$, while the height of the top of the plume was observed to increase with latitude. In connection with the presence of the monsoon flow, smaller reflectivity values were observed below the dust plume along the entire transect, partly because of the much lower aerosol content to which the lidar is sensitive, and partly in connection with the attenuation experienced by the laser beam while propagating though the dust plume. Extinction was evident in the lower $1.5 \mathrm{~km}$ of the atmosphere to the north of $12^{\circ} \mathrm{N}$ on 13 June (Figure $14(\mathrm{a}-\mathrm{c})$ ). South of $11^{\circ} \mathrm{N}$, over the continent, cumulus clouds were observed below the dust plume which marked the top of the monsoon layer. They are characterized by large ABC values (in excess of 200). In some instances, these clouds were observed to penetrate the dust plume (e.g. at $\left.6.5^{\circ} \mathrm{N}\right)$.

\subsection{Vertical distribution of dust after the passage of the MCS}

On 14 June, north of $6.5^{\circ} \mathrm{N}$, the LEANDRE 2-derived $\mathrm{ABC}$ field along the same transect exhibited lower values than on the previous day above the monsoon flow (Figure 13(b)). The latitudinal structure of the altitude of the plume top on 14 June was very similar to that observed on 13 June. However, it was observed to extent further south, above the marine PBL clouds. Also, north of $10^{\circ} \mathrm{N}$, the $\mathrm{ABC}$ was observed to exhibit much less vertical variability. The presence of cumulus clouds at the top of the monsoon layer is consistent with the MSG/SEVIRI classification (Figure 10(b)).

Figure $14(\mathrm{a}-\mathrm{c})$ suggests that the altitude of the top of the dust plume north of $10^{\circ} \mathrm{N}$ was lower by at least several hundred metres on 14 June than on 13 June. This is

Table I. Dropsonde release times and positions along the F/F20 flight track on 13 and 14 June 2006.

\begin{tabular}{llllllllllllll}
\hline & Dropsonde No. & 1 & 2 & 3 & 4 & 5 & 6 & 7 & 8 & 9 & 10 & 11 & 12 \\
\hline 13 June & Latitude $\left({ }^{\circ} \mathrm{N}\right)$ & 15 & 14 & 13 & 12 & 10.42 & 10 & 9 & 8 & 7 & 6 & 5 & 4 \\
& Longitude $\left({ }^{\circ} \mathrm{E}\right)$ & 1.5 & 1.5 & 1.5 & 1.5 & 1.5 & 1.5 & 1.5 & 1.5 & 1.5 & 1.5 & 1.5 & 1.5 \\
& Time $(\mathrm{UTC})$ & 1137 & 1147 & 1158 & 1208 & 1224 & 1228 & 1239 & 1248 & 1258 & 1308 & 1318 & 1328 \\
\hline 14 June & Latitude $\left({ }^{\circ} \mathrm{N}\right)$ & - & - & - & - & - & 10 & - & - & - & - & - & - \\
& Longitude $\left({ }^{\circ} \mathrm{E}\right)$ & - & - & - & - & - & 2.33 & - & - & - & - & - & - \\
& Time (UTC) & - & - & - & - & - & 1406 & - & - & - & - & - & - \\
\hline
\end{tabular}



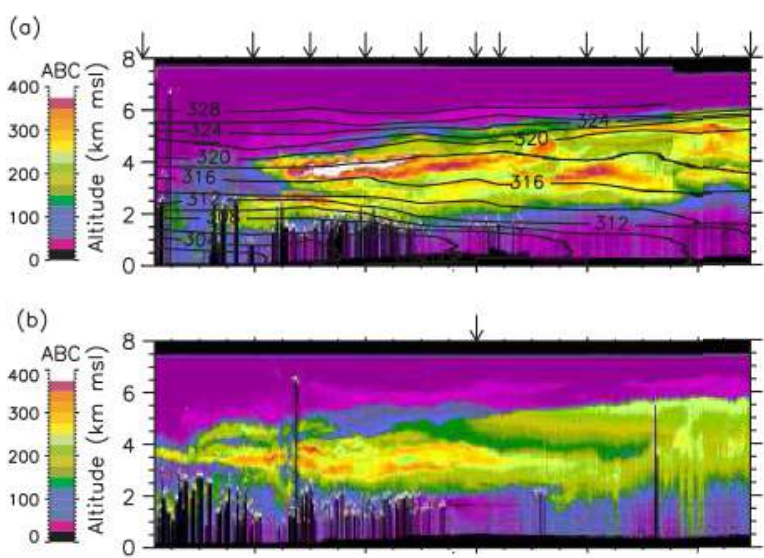

(c)

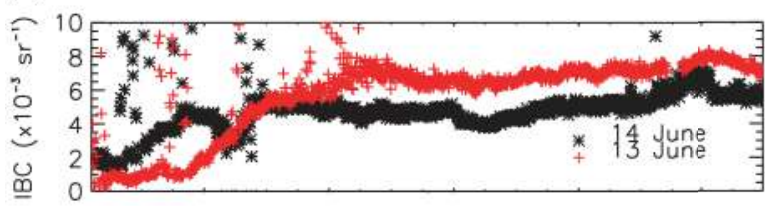

(d)

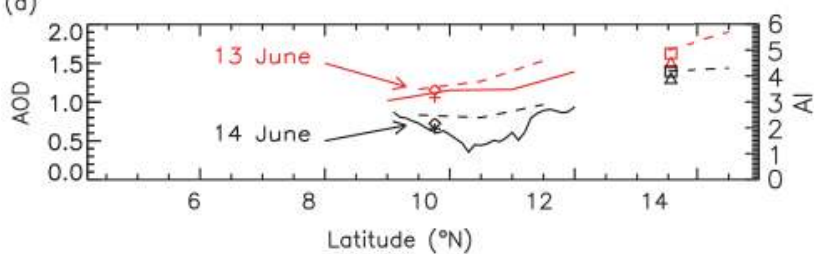

Figure 13. (a) LEANDRE-derived attenuated backscatter coefficient at $732 \mathrm{~nm}\left(\times 10^{-5} \mathrm{~km}^{-1} \mathrm{sr}^{-1}\right)$ along the $\mathrm{F} / \mathrm{F} 20$ track on 13 June 2006 (colour) with superimposed isentropes (contoured every $2 \mathrm{~K}$ ) interpolated from the eleven dropsondes (Figure 12). The arrows indicate the location of the dropsondes released along the transect. (b) is as (a), showing $A B C$ only on 14 June 2006. (c) Integrated particle backscatter coefficient associated with the dust plume (above the monsoon flow) on 13 June (red crosses) and 14 June (black asterisks). (d) MODIS/AQUA-derived AOD along the F/F20 flight track on 13 and 14 June 2006 (solid red and black lines, respectively). The MODIS data were extracted from two high-resolution granules and are cloudscreened. OMI-derived AI along the F/F20 flight track on 13 and 14 June 2006 appear as dashed red and black lines, respectively. (OMI data are shown in cloud-free regions only.) Data south of $8.5^{\circ} \mathrm{N}$ have been discarded as being contaminated by low-level clouds (Figure 10(b)), and data between $12^{\circ} \mathrm{N}$ and $13.5^{\circ} \mathrm{N}$ have been discarded as being contaminated by high-level clouds (Figure 10(c)). AOD at $440 \mathrm{~nm}$ and $670 \mathrm{~nm}$ were derived from sun-photometer measurements in Djougou (diamonds and crosses, respectively) and Banizoumbou (squares and triangles, respectively) at 1230 UTC on 13 June (red symbols) and at 1400 UTC on 14 June (black symbols). This figure is available in colour online at www.interscience.wiley.com/journal/qj

thought to be related to the subsidence affecting the lower troposphere in the wake of the MCS, as discussed in section 5 . South of $10^{\circ} \mathrm{N}$, the widespread subsidence does not appear to be strong enough to prevent the formation of cumulus clouds at the top of the monsoon layer.

In the region between $9.5^{\circ} \mathrm{N}$ and $11^{\circ} \mathrm{N}$ (Figure 13(b)), a region where such clouds were observed on 13 June, the absence of clouds at the top of the monsoon flow could also be linked to the mesoscale atmospheric circulations associated with the existence of a sharp gradient of soil moisture as previously discussed (section 5). Enhanced subsidence over wetter surfaces in the lower $1-2 \mathrm{~km}$ of the troposphere linked with such circulation would be detrimental to the formation of cumuli. This is consistent with the dropsonde measurements at $10^{\circ} \mathrm{N}$ (i.e. slightly north of Djougou, Figure 15), which show that the monsoon layer is shallower on 14 than on 13 June (Figure 15(a,c,d)). On the other hand, enhanced ascending motion over drier surfaces would favour the formation of cumuli, such as those observed north of $11^{\circ} \mathrm{N}$ on Figure 13(b). Further interpretation of the dropsonde moisture, wind and temperature data in the lower $2 \mathrm{~km}$ is beyond the scope of this paper as the dropsondes was released almost right on the soil moisture gradient feature, and the data likely reflect complex surface-atmosphere interactions in this region.

Finally, it is worth noting that the maximum value of wind speed in the AEJ is shifted upwards on 14 June by $1.2 \mathrm{~km}$ (Figure 15(b)). This was also observed in the radiosonde wind profiles obtained at Parakou (Benin; Figure 1) at 0900 and 1600 UTC. Lidar reflectivity measurements at $10^{\circ} \mathrm{N}$ indicate that the reduction of dust content between 13 and 14 June essentially occurred above $3.3 \mathrm{~km}$ agl (Figure 14(d)). The maximum of wind in the AEJ on 14 June is observed to be within the upper part of the dust plume, i.e. the region of the plume characterized by a decrease in aerosol content (Figure 15(b)). This suggests differential advection of cleaner air masses in the upper SAL. Similarly, the stripe of reduced reflectivity observed in Figure 13(b) and in Figure 14 between $8.5^{\circ} \mathrm{N}$ and $13^{\circ} \mathrm{N}$ around $4 \mathrm{~km}$ amsl is possibly related to the same process.

As discussed above, lidar reflectivity measurements suggest that the dust load in the SAL on 14 June was reduced below that of 13 June (Figure 14). There is evidence of weaker laser beam extinction north of $12^{\circ} \mathrm{N}$ on 14 June (Figure 14(a-c)) which is also an indication of the lower aerosol content above the monsoon layer. The reduction of the $\mathrm{ABC}$ values in the $\mathrm{SAL}$ was further quantified by computing the integrated particle backscatter coefficient from each $\mathrm{ABC}$ profile along the transect (Figure 13(c)). Spurious values are caused by the presence of cumulus clouds penetrating the dust plume. Except around $14^{\circ} \mathrm{N}$, the integrated particle backscatter coefficient north of $8^{\circ} \mathrm{N}$ was larger on 13 June than on 14 June. This is consistent with both the evolution of the MODIS-derived AOD and OMI-derived AI along the F/F20 track on 13 and 14 June, as well as sunphotometer-derived AOD measurements at Djougou and Banizoumbou at the time of the F/F20 overpasses on these days (Figure 13(d)). Larger AI (AOD) values were observed on 13 June than on 14 June, north of $7^{\circ} \mathrm{N}$ $\left(9^{\circ} \mathrm{N}\right)$. At Djougou, AOD values at $440 \mathrm{~nm}(675 \mathrm{~nm})$ decreased from 1.12 (1.06) at 1230 UTC on 13 June to $0.72(0.66)$ at 1400 UTC on 14 June. At Banizoumbou, the AOD reduction was not as drastic as values varied from 1.62 (1.51) to 1.39 (1.31), which is also consistent with lidar data in this region, and is thought to be related to local conditions in the area. It is interesting to note that there is a significant increase in boundary-layer dust between the 13 and 14 June at $14^{\circ} \mathrm{N}$ (Figure 14(a)). MSG/SEVIRI images do show that isolated convective systems developed between 1200 and 1400 UTC along 

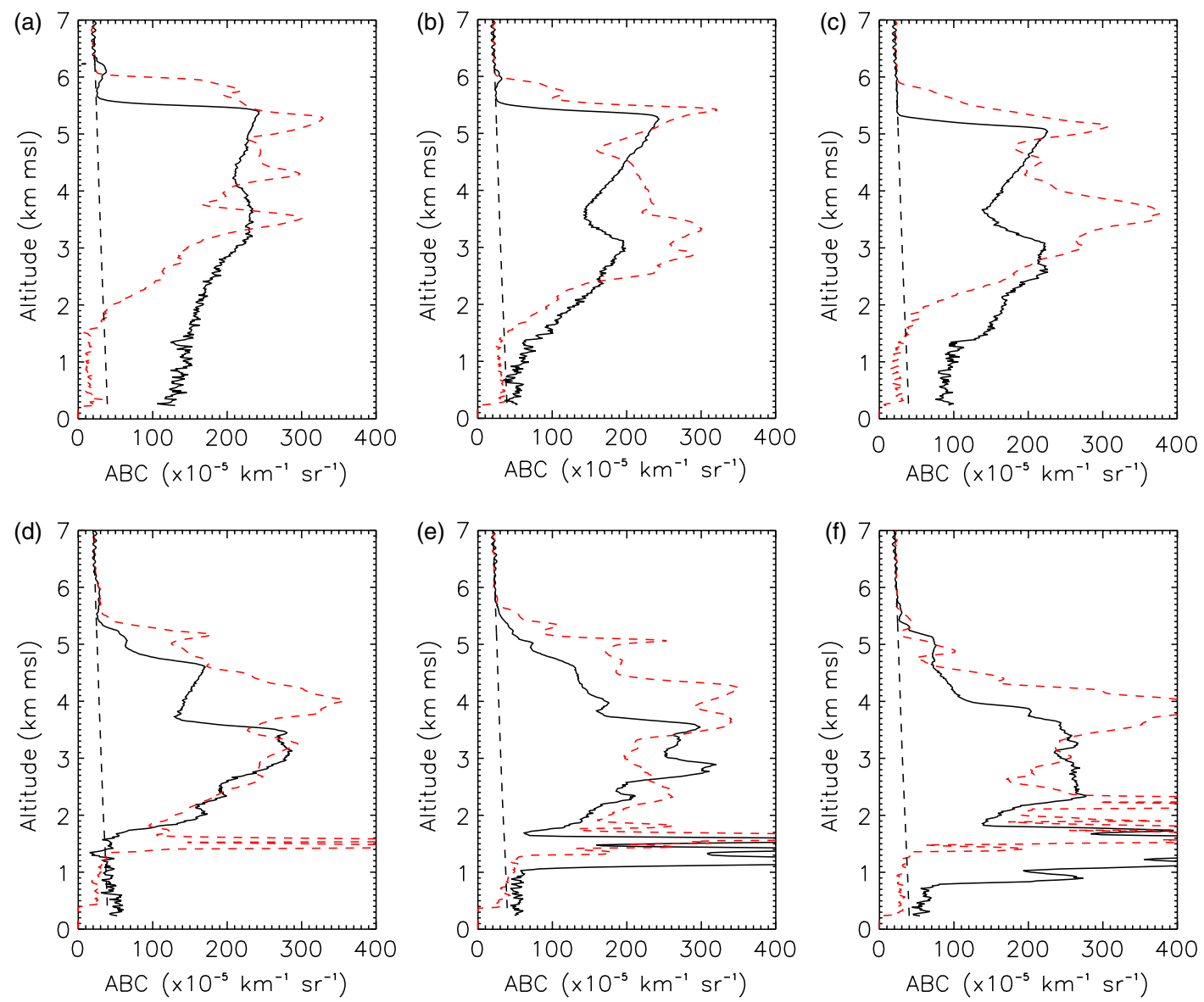

Figure 14. Profiles of LEANDRE-derived normalized attenuated backscatter coefficient at 732 nm on 13 June (dashed red line) and 14 June (solid black line), and dropsonde-derived molecular backscatter coefficient (dashed black line) at (a) $14^{\circ} \mathrm{N},(\mathrm{b}) 13^{\circ} \mathrm{N},(\mathrm{c}) 12^{\circ} \mathrm{N},(\mathrm{d}) 10^{\circ} \mathrm{N},(\mathrm{e})$ $9^{\circ} \mathrm{N}$, (f) $8^{\circ} \mathrm{N}$ (other details are in Table I). This figure is available in colour online at www.interscience.wiley.com/journal/qj
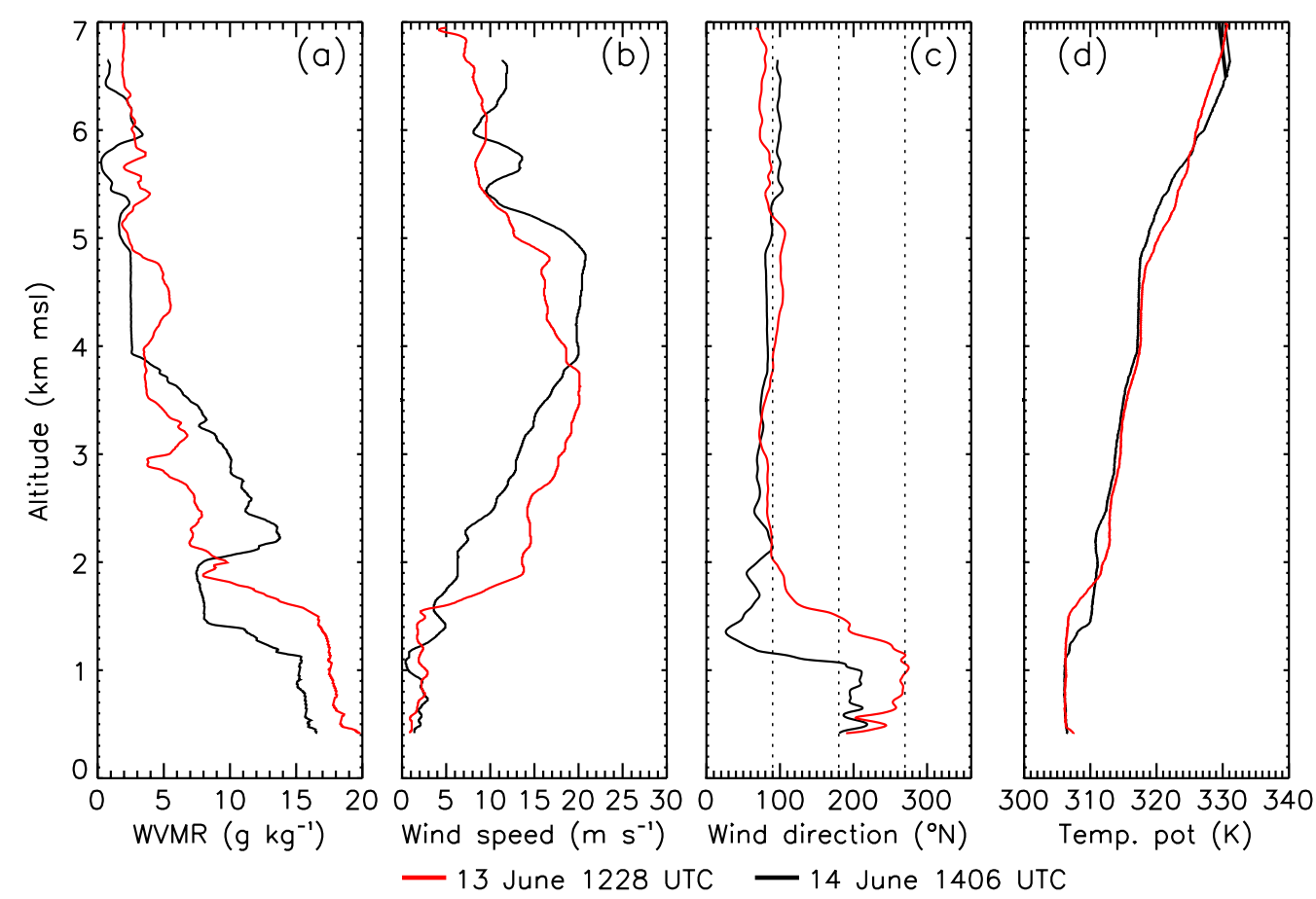

Figure 15. (a) Water vapour mixing ratio, (b) wind speed, (c) wind direction and (d) potential temperature derived from dropsonde measurements performed at $10^{\circ} \mathrm{N}$ on 13 June (red) and 14 June (black). This figure is available in colour online at www.interscience.wiley.com/journal/qj 
the ring of clouds north of the subsidence trail of the MCS (not shown), just north of Benin. These short-lived convective systems and their related cold pools could be responsible for the dust mobilisation seen in the lidar data in the vicinity of Niamey. For instance, Williams et al. (2008) have shown that virtually every cold outflow from moist convection in the vicinity of Niamey was a source of substantial dust uplift throughout the wet season.

Lidar measurements evidence that the reduction of the dust load over Benin and southern Niger occurred consistently north of $8^{\circ} \mathrm{N}$ (this is corroborated at the local scale by AERONET and MODIS AODs), which suggests that this decrease is mostly related to the variability of the dust load upstream. The vertical distribution of dust upstream of Benin is now analysed using CALIOP data.

\subsection{Vertical distribution of dust upstream}

The structure of the dust plume to the south of $15^{\circ} \mathrm{N}$ over Benin on 14 June (Figure 13(b)), was observed to be quite similar to that derived from the CALIOP measurements acquired during the overpass between 1236 and 1241 UTC on 13 June, just west of the Chad border (Figure 16(a)); a thinner plume characterised by higher $\mathrm{ABCs}$ was observed to the south, while a deeper plume characterized by lower ABCs were observed to the north. The back trajectory analyses suggest that the plume sampled by CALIOP in this region (Figure $6(\mathrm{~d}, \mathrm{f}, \mathrm{h}, \mathrm{j})$ ) may have been observed one day later over Benin and southern Niger at the time of the airborne operations (i.e. 1400 UTC on 14 June, Figure 13(b)). Ideally, one would want to compare the characteristics of the plume on 12 June around midday in the same region, in order to assess whether the reduction in dust load observed over Benin between 13 and 14 June could be related to a reduction of the dust load upstream as observed by CALIOP. Unfortunately, no CALIOP data are currently available before 13 June 2006.

(a)

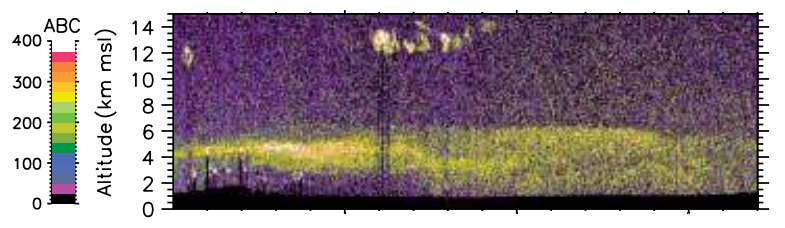

(b)

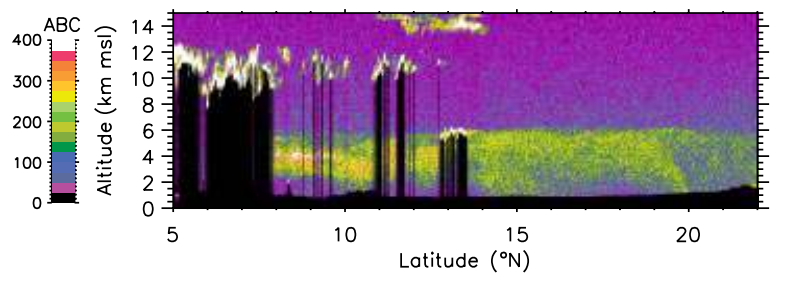

Figure 16. (a) CALIPSO lidar-derived attenuated backscatter coefficient at $532 \mathrm{~nm}\left(10^{-5} \mathrm{~km}^{-1} \mathrm{sr}^{-1}\right)$ along the CALIPSO track on 13 June 2006 between 1236 and 1241 UTC. (b) is as (a), but on 14 June 2006 between 0050 and 0055 UTC. This figure is available in colour online at www.interscience.wiley.com/journal/qj
Instead, we have verified the consistency of trends in the dust distribution observed with CALIOP at 12361241 UTC on 13 June (Figure 16(a)) and 0050-0055 UTC on 14 June (Figure 16(b)) upstream from Benin and southwestern Niger. Averaged CALIOP-derived ABC profiles were computed between $8^{\circ} \mathrm{N}$ and $11^{\circ} \mathrm{N}$ (Figure $17(\mathrm{a})$ ) as well as between $14^{\circ} \mathrm{N}$ and $17^{\circ} \mathrm{N}$ (Figure 17(b)), on both days. According to the back trajectory analyses, these profiles can be considered as representative of the evolution of the dust distribution upstream of the AERONET stations of Djougou (cf. Figures 17(b) and 14(d)) and Banizoumbou (cf. Figures 17(a) and 14(b)), respectively. The comparison suggests that the decrease observed over Benin (Djougou) and southern Niger (Banizoumbou) between 13 and 14 June is related to a decrease in the dust load upstream. Furthermore, the fact that the upstream dust layer height to the north
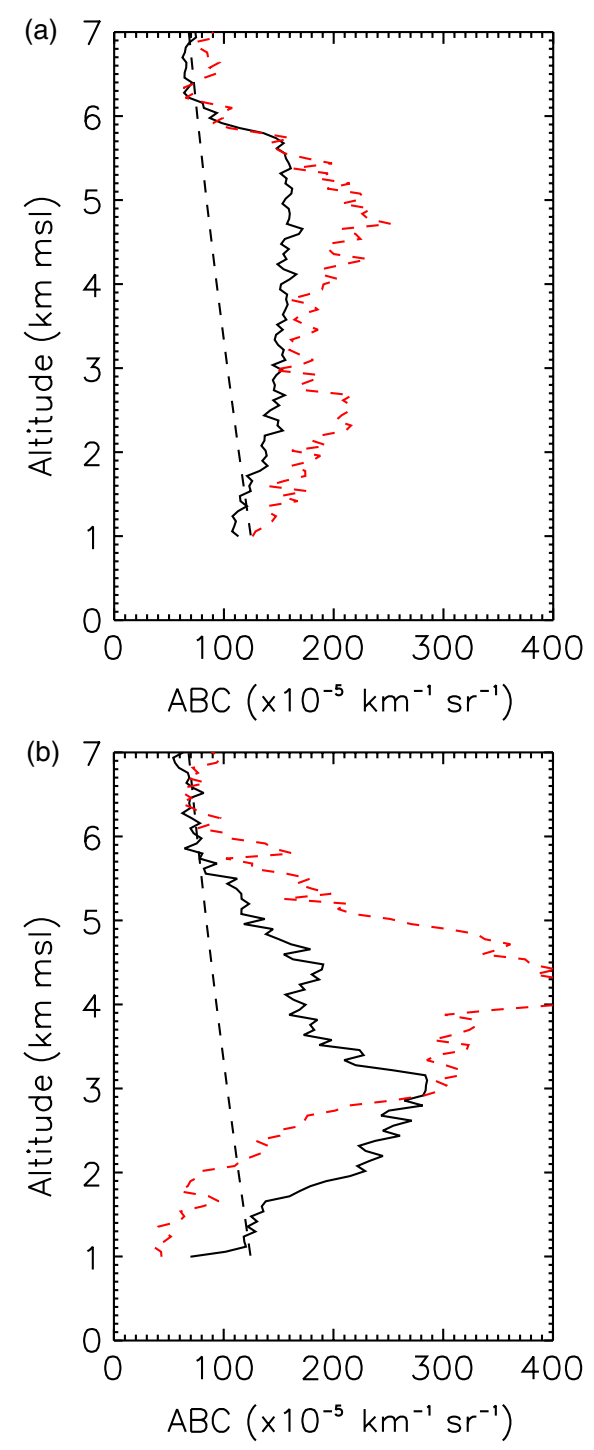

Figure 17. Profiles of CALIPSO lidar-derived normalized attenuated backscatter coefficient at $532 \mathrm{~nm}$ on 13 June (dashed red line) and 14 June (solid black line), and dropsonde-derived molecular backscatter coefficient (dashed black line) between (a) $14^{\circ} \mathrm{N}$ and $17^{\circ} \mathrm{N}$ and (b) $8^{\circ} \mathrm{N}$ and $11^{\circ} \mathrm{N}$. This figure is available in colour online at www.interscience.wiley.com/journal/qj 
does not change between 13 and 14 June (Figure 17(a)), suggests that the lowering of the dust layer-top height over Niger may be imputable to the subsidence in the wake of the MCS. On the other hand, the structural similarities in the vertical distribution of dust between the profiles upstream (Figure 17(b)) over southern Benin (Figure 14(d)) on both days, suggest that profiles over Benin may be influenced more by upstream conditions than by the subsidence in the wake of the MCS.

Finally, it is worth noting that the structure of the dust plume observed by CALIOP on 13 and 14 June west of Chad provides evidence of the existence of a cleaner layer (i.e. characterized by a lower lidar apparent backscatter coefficient) underneath the dust plume. This layer corresponds to the monsoon, which is seen to reach $14-15^{\circ} \mathrm{N}$, consistent with the ECMWF analysis (Figure 7).

\section{Summary and conclusions}

This study presents the most detailed analysis to date of a representative late spring dust emission/ transport/deposition event from the Bodélé depression and northern Sudan, using a consistent set of multi-platform observations over West Africa. Ground-based, airborne and satellite observations, as well as ECMWF data, were used for this purpose.

The results illustrate the importance of knowledge of the time-evolving three-dimensional distribution at the regional scale of dust when attempting to establish the impact of dust on the Earth's radiative budget over Africa.

The study shows that day-to-day variability in emission from known dust sources in the Bodélé depression, Chad and northern Sudan is associated with variability in the strength of the northeasterly LLJs over these regions. AOD over source regions was observed to depend on the strength of the nocturnal LLJ during the preceding night. High correlation coefficients between the averaged $925 \mathrm{hPa}$ winds extracted from the ECMWF analyses at 0600 UTC and the MODIS Deep Blue-derived AODs around midday the same day were obtained over the Bodélé, west Sudan and east Sudan regions (0.87, 0.89 and 0.94 , respectively). To the best of the authors' knowledge, this is the first observational study showing the importance of the LLJ for the dust mobilization over Sudan. Dust is subsequently transported from these eastern Saharan sources southwest towards the Sahel and the Gulf of Guinea. In the late spring, the ITD acts to raise the aerosol layer over the southwesterly monsoon flow (as previously reported by Hamilton and Archbold, 1945; Parker et al., 2005), and into the AEJ core which ensures fast westward transport across the continent. This study also highlights the role of orography (Darfur and Ennedi mountains) in this process which, again to our knowledge, has never been reported before.

The possible impact of an MCS on the dust load and vertical distribution was investigated nearly 12 hours after its passage over Benin by a suite of groundbased, airborne and space-borne instruments. The only discernible impact on the dust distribution is observed to be associated with widespread subsidence in the wake of the MCS, over northern Benin and Niger. Wet scavenging related to convective or stratiform rain could not be observed, as processed air masses were replaced by fresh dust transported in the upper Saharan aerosol layer by the AEJ, i.e. roughly at the same speed as the MCS. Over southern Benin, the dust distribution appeared to be mostly controlled by processes affecting the PBL upstream, i.e. over Nigeria or Chad.

Besides presenting a first comprehensive study of all the aspects relevant to the life cycle of dust over West Africa during a representative late spring case, the paper also offers guidance to regional and mesoscale models for evaluating important components of this life cycle. Improved understanding of the radiative impact on Sahelian and sub-Sahelian weather will not only be achieved via realistic modelling of emissions in source regions, but also via an enhanced comprehension of uplift and transport. Even though this case-study does not address it, improved understanding of the radiative impact of dust on Sahelian and sub-Sahelian weather will also come from enhanced knowledge on the processing of dust present in the atmosphere by propagating MCSs. There is a clear need for models to represent accurately not only the synoptic-scale circulation and the mesoscale flow related to topography but also moist convective processes associated with MCSs.

Finally, the results raise the questions of what impact dust aerosols may have on the structure of the AEJ itself (most notably via the aerosol 'semi-direct' effect, i.e. the impact of aerosol-induced radiative warming on dynamics). Transport of massive amounts of dust in the AEJ from remote eastern sources such as the Bodélé depression in northern Chad or the sources in west Sudan could impact on the atmospheric stratification in the AEJ region and, in turn, modify the properties of the AEJ itself, thereby possibly modifying the West African weather at the synoptic scale. This important link between the structure and the strength of the AEJ and the dust transported from the Saharan sources is yet to be addressed.

\section{Acknowledgements}

Based on a French initiative, AMMA was built by an international scientific group and is currently funded by a large number of agencies, especially from France, UK, US and Africa. It has been the beneficiary of a major financial contribution from the European Community's Sixth Framework Research Programme. Detailed information on scientific coordination and funding is available on the AMMA International web site http://www.amma-international.org. MSG observations have been delivered by Service d'Archivage et de Traitement Météorologique des Observations Spatiales (Lannion, France). The authors wish to thank the SAFIRE (Service des Avions Français Instrumentés pour la Recherche en Environnement, www.safire.fr), the 
Institut Géographique National (IGN, www.ign.fr) and the Division Technique of the Institut National des Sciences de l'Univers (DT/INSU, www.dt.insu.cnrs.fr) for preparing and delivering the research aircraft (Falcon 20/F-GBTM) and the airborne instruments in a timely manner for the AMMA SOP. They also wish to thank the AMMA Operation Centre and their partners across West Africa for smoothing out many aspects of the airborne operations. The authors are grateful to D. Bruneau and P. Genau (Service d'Aéronomie), F. Blouzon, A. Abchiche, D. Chaize and N. Amarouche (DT/INSU) for refitting and operating the LEANDRE 2 system in the F/F20. Special thanks go to A. Gribkoff, R. Cailloux and M. Laurens (SAFIRE) for operating the dropsonde system. J. P. Cammas (Laboratoire d'Aérologie) is thanked for providing the dropsonde data. R. T. Pinker, P. Goloub, D. Tanré and J.-L. Rajot are thanked for the Ilorin, Djougou, Banizoumbou and Maine-Soroa sun-photometer data, respectively. C. Taylor (Centre for Ecology and Hydrology) is thanked for feedback on the manuscript. C. Galy-Lacaux (Laboratoire d'Aérologie) and M. Gosset (Laboratoire d'Etude des Transferts Hydrologiques et Environnement) are thanked for discussions on an earlier version of this manuscript. The authors wish to thank J. Marsham (School of Earth and Environment, University of Leeds) for his detailed comments that have improved the paper.

\section{References}

Bou Karam D, Flamant C, Knippertz P, Reitebuch O, Pelon J, Chong M, Dabas A. 2008. Dust emissions over the Sahel associated with the West African monsoon intertropical discontinuity region: A representative case-study. Q. J. R. Meteorol. Soc. 134: 621-634.

Bruneau D, Quaglia P, Flamant C, Meissonnier M, Pelon J. 2001. Airborne lidar LEANDRE II for water-vapor profiling in the troposphere. Appl. Opt. 40: 3450-3475.

Chaboureau JP, Tulet P, Mari C. 2007. Diurnal cycle of dust and cirrus over West Africa as seen from the Meteosat Second Generation satellite and a regional forecast model. Geophys. Res. Lett. 34: L02822, DOI: 10.1029/2006GL027771.

Engelstaedter S, Washington R. 2007. Atmospheric controls on the annual cycle of North African dust. J. Geophys. Res. 112: D03103, DOI: $10.1029 / 2006 J D 007195$.

Fan SM, Horowitz LW, Levy II H, Moxim WJ. 2004. Impact of air pollution on wet deposition of mineral dust aerosols. Geophys. Res. Lett. 31: L02104, DOI: 10.1029/2003GL0118501.

Flamant C, Chaboureau JP, Parker DP, Taylor CM, Cammas JP, Bock O, Timouk F, Pelon J. 2007. Airborne observations of the impact of a convective system on the planetary boundary layer thermodynamics and aerosol distribution in the intertropical discontinuity region of the West African Monsoon. Q. J. R. Meteorol. Soc. 133: $1175-1189$.

Hamilton RA, Archbold JW. 1945. Meteorology of Nigeria and adjacent territory. Q. J. R. Meteorol. Soc. 71: 231-264.
Haywood JM, Allan RP, Culverwell I, Slingo A, Milton S, Edwards J, Clerbaux N. 2005. Can desert dust explain the outgoing longwave radiation anomaly over the Sahara during July 2003? J. Geophys. Res. 110: D05105.

IPCC. 2008. Climate Change and Water. Tech. paper of the Intergovernmental Panel on Climate Change. Bates BC, Kundzewicz ZW, Wu S, Palutikof JP (eds.) Available from http://www.ipcc.ch/ipccreports/tp-climate-change-water.htm.

Knippertz P. 2008. Dust emissions in the West African heat trough - The role of the diurnal cycle and of extratropical disturbances. Meteorol. Z. 17: 553-563.

Marsham JH, Parker DJ, Grams CM, Taylor CM, Haywood JH. 2008. Uplift of Saharan dust at the inter-tropical discontinuity. J. Geophys. Res. 113: D21102, DOI: 10.1029/2008JD009844.

Parker DJ, Thorncroft CD, Burton RR, Diongue A. 2005. Analysis of the African Easterly Jet using aircraft observations from the JET2000 experiment. Q. J. R. Meteorol. Soc. 131: 1461-1482.

Prospero JM, Ginoux P, Torres O, Nicholson SE, Gill TE. 2002. Environmental characterization of global sources of atmospheric soil dust identified with the Nimbus 7 total ozone mapping spectrometer (TOMS) absorbing aerosol product. Rev. Geophys. 40: 1, DOI: 10.1029/2000RG000095.

Redelsperger J-L, Thorncroft CD, Diedhiou A, Lebel T, Parker DJ, Polcher J. 2006. African Monsoon Multidisciplinary Analysis: An international research project and field campaign. Bull. Am. Meteorol. Soc. 87: 1739-1746.

Sterk G. 2002. Causes, consequences and control of wind erosion in Sahelian Africa: A review. Land Degrad. Dev. 14: 1331-1344.

Taylor CM, Parker DJ, Harris PP. 2007. An observational case study of mesoscale atmospheric circulations induced by soil moisture. Geophys. Res. Lett. 34: L15801.

Thorncroft CD, Parker DJ, Burton RR, Diop M, Ayers JH, Barjat H, Devereau S, Diongue A, Dumelow R, Kindred DR, Price NM, Saloum M, Taylor CM, Tompkins AM. 2003. The JET2000 project: Aircraft observations of the African Easterly Jet and African Easterly Waves. Bull. Am. Meteorol. Soc. 84: 337-351.

Todd MC, Washington R, Lizcano G, Ragvahan S, Knippertz P. 2008. Regional model simulations of the Bodélé low-level jet of northern Chad during the Bodélé Dust Experiment (BoDEx 2005). J. Climate 21: 995-1012.

Tompkins AM, Cardinali C, Morcrette JJ, Rodwell M. 2005. Influence of aerosol climatology on forecasts of the African Easterly Jet. Geophys. Res. Lett. 32: L10801.

Washington R, Todd MC. 2005. Atmospheric controls on mineral dust emission from the Bodélé depression, Chad: The role of the low-level jet. Geophys. Res. Lett. 32: L17701, DOI: 10.1029/2005GL023597.

Washington R, Todd MC, Middleton NJ, Goudie AS. 2003. Duststorm source areas determined by the Total Ozone Monitoring Spectrometer and surface observations. Ann. Assoc. Amer. Geograph. 93: $297-313$.

Washington R, Todd MC, Engelstaedter S, Mbainayel S, Mitchell F. 2006. Dust and the low-level circulation over the Bodélé depression, Chad: Observations from BoDEx 2005. J. Geophys. Res. 111: D03201, DOI: 10.1029/2005JD006502.

Williams E, Nathou N, Hicks E, Pontikis C, Russell B, Miller M, Bartholomew MJ. 2008. The electrification of dustlofting gust fronts ('haboobs') in the Sahel. Atmos. Res. DOI: 10.1016/j.atmosres.2008.05.017, in press.

Winker DM, Hunt WH, McGill MJ. 2007. Initial performance assessment of CALIOP. Geophys. Res. Lett. 34: L19803, DOI $10.1029 / 2007$ GL030135. 